\title{
2019 DeVelopments in Indiana Evidentiary Practice
}

\author{
COLIN E. FLORA*
}

This survey covers developments in all aspects of Indiana's evidence law between October 1, 2018 and September 30, 2019. Consistent with the practice of this survey since the 1996 edition, ${ }^{1}$ developments are addressed in the same order as the Indiana Rules of Evidence followed by analysis of common-law and statutory evidentiary practices. The survey period included several major developments with issues ranging from whether an expert may be impeached based on an unrelated history of professional discipline ${ }^{2}$ to granting a new trial because pre-injury nonuse of safety equipment was errantly admitted. ${ }^{3}$ As the decisions from this period help to refine evidentiary practice, they also serve as a reminder that there will always be areas of uncertainty in need of further clarification. $^{4}$

\section{GENERAL PROVISIONS: RULES 101 THROUGH 106}

\section{A. Rule 101: To What Do the Rules Apply}

The scope and general applicability of the Indiana Rules of Evidence are established by Rule $101 .^{5}$ Despite generally applying to "all proceedings in the courts of the State of Indiana," most of the rules of evidence do not apply. ${ }^{7}$ In all such proceedings, however, the rules regarding privilege remain undisturbed. ${ }^{8}$ Highlighted during the survey period was that the Indiana Rules of Evidence do not apply to probationrevocation proceedings. ${ }^{9}$ Accordingly, it was not error for a trial court to admit field-test results that concluded a crystal substance was methamphetamine in a

* Associate Attorney, Pavlack Law, LLC in Indianapolis, Indiana; J.D., 2011, cum laude, Indiana University Robert H. McKinney School of Law; B.A., 2008, with high distinction, Indiana University South Bend. The author also manages the Hoosier Litigation Blog, which focuses on legal developments affecting Indiana practitioners.

1. Edward F. Harney, Jr. \& Jennifer Markavitch, 1995 Survey of Indiana Evidence Law, 29 IND. L. REv. 887 (1996); see, e.g., Yvonne M. Dutton, Recent Developments in Indiana Evidence Law: October 1, 2014 to September 30, 2015, 49 IND. L. REV. 1053 (2016).

2. Tunstall v. Manning, 124 N.E.3d 1193, 1197-98 (Ind. 2019).

3. Webber v. Butner, 922 F.3d 479 (7th Cir. 2019) (Indiana law).

4. "“[I]t would be very hard upon the profession if the law was so certain that everybody knew it; the misfortune is that it is so uncertain that it costs much money to know what it is even in the last resort.'” Daily v. Bd. of Comm'rs, 165 Ind. 99, 106, 74 N.E. 977, 979 (1905) (quoting Jones v. Randall, (1774) 1 Cowp. 37, 40, 98 Eng. Rep. 954, 956).

5. See IND. R. EvID. 101(a) \& (b).

6. IND. R. Evid. 101(b).

7. See generally IND. R. EvID. 101(d).

8. $I d$.

9. Votra v. State, 121 N.E.3d 1108, 1113 (Ind. Ct. App. 2019) (citing IND. R. EvID. 101(d)(2)). 
probation-revocation proceeding. ${ }^{10}$

\section{B. Rule 103: Preserving Evidentiary Rulings for Appeal}

One of the most indispensable skills for trial counsel is the ability to object not only for the purpose of excluding evidence at trial, but also for the purpose of preserving a claim of error for appeal. ${ }^{11}$ The steps for securing the right to review evidentiary rulings are provided by Rule $103 .{ }^{12}$ Where a subsequent challenge is to the admission of evidence, the error is preserved only if trial counsel timely objects and provides a basis for the objection, unless the basis is readily apparent from the record. ${ }^{13}$ If evidence was excluded, "counsel must inform the court of the evidence's substance by an offer of proof, allowing for meaningful review on appeal." 14

The mere preservation of error, however, does not mean an appellate court may reverse. In addition to the burden of overcoming a finding of harmless error, ${ }^{15}$ challenges to evidentiary rulings confront the additional hurdle that the error must have "affect[ed] a substantial right of the party." "The survey period provides numerous instances in which the Indiana Court of Appeals rejected challenges on the ground that the evidence, even if improperly admitted, did not implicate a substantial right of the party. Two illustrative examples are K.H. v. Cochran ${ }^{17}$ and Tavake v. State. ${ }^{18}$ In K.H., the court rejected a challenge to an award of custody to a father that was based in part on the conclusion that the mother's mental-health status impaired her ability to effectively parent. ${ }^{19}$ The appellate court concluded that even if a survey relating to the mother's mental health was improperly admitted, it was "only part of a psychological evaluation that encompassed many other sources of information, including Mother's clinical interview and two other assessment tools that Mother does not challenge on

10. Id. at 1115 .

11. Weisheit v. State, 109 N.E.3d 978, 1008 (Ind. 2018) (Rush, C.J., concurring in part and dissenting in part).

12. IND. R. EvID. 103.

13. IND. R. EvID. 103(a)(1). In instances of fundamental error, a subsequent challenge may be made even absent proper preservation. IND. R. EvID. 103(e); see, e.g., Cleveland v. State, 129 N.E.3d 227, 232 n.6 (Ind. Ct. App.) ("The record shows that Cleveland did not object to preserve this issue for appeal, so we can only review it for fundamental error."), trans. denied, 137 N.E.3d 920 (Ind. 2019).

14. Weisheit, 109 N.E.3d at 1008 (Rush, C.J., concurring in part and dissenting in part) (citing IND. R. EVID. 103(a)(2)).

15. IND. R. APP. P. 66(A).

16. IND. R. Evid. 103(a); see, e.g., Saintignon v. State, 118 N.E.3d 778, 789 (Ind. Ct. App.) ("No claim of error in the admission of photographs is permitted unless a substantial right of the party is affected."), trans. denied, 124 N.E.3d 46 (Ind. 2019).

17. 116 N.E.3d 504 (Ind. Ct. App. 2018), trans. denied, 123 N.E.3d 144 (Ind. 2019).

18. 131 N.E.3d 696 (Ind. Ct. App.), trans. denied, 134 N.E.3d 1021 (Ind. 2019).

19. K.H., 116 N.E.3d at 508-09 \& 513. 
appeal" and that were independently sufficient for the trial court to have reached its conclusions. ${ }^{20}$

Similarly, Tavake rejected a challenge on the basis that a criminal defendant's California correctional records did not redact "186.22(B)(1)," "a reference to California Penal Code section 186.22, which criminalizes participation in a criminal street gang." ${ }^{11}$ Because "there [wa]s no suggestion that the jury had the resources to decipher this citation, and the FBI card contained no indication that it referred to an additional criminal conviction," the court found no error in including the evidence, even though it was likely irrelevant. ${ }^{22}$

Another area garnering the attention of Indiana's appellate courts was the use of offers of proof to preserve challenges to excluded evidence. "[A]n offer of proof is required to preserve an error in the exclusion of a witness's testimony." 23 "Offers of proof benefit not only the parties and the trial court, but they are invaluable to reviewing courts." ${ }^{24}$ A case presented to the Indiana Court of Appeals showed that even if an offer of proof was prematurely terminated and could have included additional information, the trial court's premature cessation of the offer is harmless error if "[e]nough evidence was presented" to permit appellate review. ${ }^{25}$

Not all limitations on offers of proof as easily withstand appellate scrutiny, as seen in Bedolla v. State, decided by the Indiana Supreme Court. ${ }^{26}$ The court instructed:

[W] hen a party asks to make a legitimate offer of proof, the trial court should grant that request. Of course, as part of its duty to impartially control a proceeding, the court may exercise reasonable discretion in determining the timing and extent of an offer of proof. But nevertheless, absent clear abuse by a party, offers of proof should be allowed. ${ }^{27}$

The trial court, reviewing a petition for post-conviction relief, "abused its discretion in preventing [c]ounsel from making an offer of proof concerning [a witness]'s anticipated testimony[, which defendant] believed ... [was able to] prove [defendant]'s actual innocence." 28 "[T] hearing only the State's argument, refused to listen to [c]ounsel's offer of proof and warned that a deputy would remove her if she did not yield her spot at

20. Id. at 513 .

21. Tavake, 131 N.E.3d at 707.

22. Id.

23. Heckard v. State, 118 N.E.3d 823, 828 (Ind. Ct. App.), trans. denied, 127 N.E.3d 234 (Ind. 2019).

24. Bedolla v. State, 123 N.E.3d 661, 667 (Ind. 2019) (alteration, citation, and quotation marks omitted).

25. Heckard, 118 N.E.3d at 829.

26. 123 N.E.3d at 667-68.

27. Id. at 667 (citations and quotation marks omitted).

28. Id. 
counsel's table."29 That response, the supreme court concluded, was unreasonable and amounted to an abuse of discretion. ${ }^{30}$

A complicated issue of trial practice is preserving an objection without becoming a nuisance to the court or risking prejudice with the jury by frequent and persistent interruptions on grounds already rejected by the trial court. ${ }^{31}$ One method of resolving that problem is through a continuing objection. In accordance with Rule 103(b), "[o]nce the court rules definitively on the record at trial a party need not renew an objection or offer of proof to preserve a claim of error for appeal." ${ }^{32}$ The survey period provided examples both of how to properly register a continuing objection and when an objection will be deemed insufficient.

In Cleveland v. State, it was found that a single objection to introduction of evidence obtained from a search was not a continuing objection and insufficient to cover a criminal defendant's statement that a firearm found in the search was his. ${ }^{33}$ Bailey v. State provided an example on the opposite end of the spectrum..$^{34}$ At trial, the defendant objected to testimony regarding a search and to fentanyl found during the search.$^{35}$ Moreover, during a hearing outside the presence of the jury, the trial court "noted . . . it would treat its denial of [the] motion to suppress as Defendant's ruling under Evidence Rule 103(b)." ${ }^{" 36}$ Based upon that record, the court of appeals easily found adequate preservation for review. ${ }^{37}$

\section{Rule 104: Preliminary Questions About Admissibility of Evidence}

The task of resolving preliminary questions on admissibility of evidence rests squarely with the trial court. $^{38}$ The precise mechanics of making such determinations twice drew the attention of the Indiana Court of Appeals, during the survey period. The first instance provides guidance for courts addressing preliminary questions. In Rose v. State, the appellate tribunal addressed a trial

29. Id.

30. Id. at 667-68.

31. Cf. Wilson v. Williams, 182 F.3d 562, 566 (7th Cir. 1999) (en banc) ("Many lawyers suppose that it is enough to raise an issue once and receive a definitive ruling. They may believe that raising the question again may annoy the judge.").

32. IND. R. EvID. 103(b). Take note of the requirement that the objection be made "at trial." Rule 103(b) of the Federal Rules of Evidence allows pre-trial determinations, while Indiana requires the objection actually be made at trial even if a pre-trial determination, such as an order in limine, has already definitively shown how the court will rule. Compare FED. R. EvID. 103(b), and Wilson, 182 F.3d at 566-67, with IND. R. EvID. 103(b), and Golden Corral Corp. v. Lenart, 127 N.E.3d 1205, 1214 (Ind. Ct. App.), trans. denied, 138 N.E.3d 948 (Ind. 2019).

33. 129 N.E.3d 227, 231, 232 n.6 (Ind. Ct. App.), trans. denied, 137 N.E.3d 920 (Ind. 2019).

34. 131 N.E.3d 665, 676 (Ind. Ct. App. 2019), trans. denied, 141 N.E.3d 30 (Ind. 2020).

35. $I d$.

36. Id.

37. Id.

38. IND. R. EvID. 104(a). 
court's decision to permit a pro se litigant's submission of all of his evidence to the court in consideration of whether to grant post-conviction relief. ${ }^{39}$ At the time of the hearing, however, the trial court had not deemed the submissions admissible, instead reserving the right to rule on admissibility after further consideration. ${ }^{40}$ Of that approach, the court of appeals remarked: "While it did not cause issue herein, we note the better practice would be to make a ruling on the admissibility of evidence during the hearing so the parties have adequate notice as to what evidence the court will use to make its decision." ${ }^{41}$

The second case, Walters $v$. State, is an important lesson for trial counsel. ${ }^{42}$ There, an authenticity challenge was made to text-message records at a pre-trial evidentiary hearing. ${ }^{43}$ The trial court, observing that Rule 104(a) frees courts resolving preliminary questions from the binds of evidence rules other than privilege, instructed objecting counsel that the evidence rules were not applicable to the determination at that juncture, resulting in counsel withdrawing the objection. ${ }^{44}$ But that did not resolve the underlying question of authenticity. ${ }^{45}$ "The trial court's refusal to address the authenticity of the records during the evidentiary hearing prior to trial [] led to confusion." ${ }^{\prime 46}$ That confusion appears to have contributed in the failure at trial to authenticate the evidence, leading to a finding of reversible error on appeal. ${ }^{47}$

\section{Rule 106: Remainder of or Related Writing or Recorded Statements}

At common law, "when a party introduce[d] part of a conversation or document, the opposing party [wa]s entitled to have the entire conversation or the entire instrument placed into evidence" by operation of the doctrine of completeness. ${ }^{48}$ The purpose was "to allow the introduction of additional material to place incomplete, misleading evidence in its full context." ${ }^{\text {"49 }}$ The doctrine of completeness has been subsumed into Rule $106,{ }^{50}$ which provides: "If a party introduces all or part of a writing or recorded statement, an adverse party may require the introduction, at that time, of any other part - or any other writing or recorded statement - that in fairness ought to be considered at the same time."

Rule 106 was unsuccessfully invoked by one litigant appearing before the

39. 120 N.E.3d 262, 265 (Ind. Ct. App.), trans. denied, 127 N.E.3d 232 (Ind. 2019).

40. Id. at $265 \mathrm{n} .2$.

41. Id.

42. 120 N.E.3d 1145 (Ind. Ct. App. 2019).

43. Id. at 1149 .

44. Id.

45. Id. at 1154 n.10.

46. Id.

47. Id. at $1153-56$.

48. McElroy v. State, 553 N.E.2d 835, 839 (Ind. 1990).

49. R.B. v. T.J. (In re B.B.), 1 N.E.3d 151, 159 (Ind. Ct. App. 2013).

50. Atwell v. State, 738 N.E.2d 332, 335 n.3 (Ind. Ct. App. 2000).

51. IND. R. EvID. 106. 
Indiana Tax Court. ${ }^{52}$ The problem with the invocation was a procedural misstep: during a show-cause hearing, the respondent moved to strike attachments to affidavits as "incomplete," but never furnished the court with the complete documents that would be needed to place the exhibits in proper context. ${ }^{53}$ By neither seeking the introduction of the remaining portions of the documents at the hearing nor submitting the missing information to the court as part of the proposed findings of fact and conclusions of law, the court had no choice but to deny the motion to strike. ${ }^{54}$

\section{JUDICIAL NOTICE: RULE 201}

Judicial notice comes in two forms: notice of facts ${ }^{55}$ and notice of law. ${ }^{56}$ The basic concept of judicial notice is that judges and "courts will not pretend to be more ignorant than the rest of mankind." ${ }^{57}$ Following the enactment of the Indiana Rules of Evidence, judicial notice is governed by both Rule 201 and Indiana's adoption of the Uniform Judicial Notice of Foreign Law Act. ${ }^{58}$ The survey period provided several examples of application of judicial notice to law and facts as well as insight into when notice is appropriate.

In accordance with Rule 201(a), there are facts that may be judicially noticed under subdivision 201(a)(1) and facts - more accurately documents - the existence of which may be noticed pursuant to 201(a)(2). ${ }^{59}$ Utilizing Rule 201(a), in an action to involuntarily terminate a mother's parental rights, the court of appeals took judicial notice of the fact that the father was convicted of aggravated battery and sentenced to nine years in prison, ${ }^{60}$ the Indiana Department of Child Services policy manual, ${ }^{61}$ and, by way of the Odyssey system, that the father was awaiting trial for sexual abuse of one of the children whose parental rights were at issue in the case. ${ }^{62}$ The Department of Child Services' policy manual was also judicially noticed in a separate case before Indiana Court of Appeals. ${ }^{63}$ Other facts that were judicially noticed by Indiana appellate courts include the geography of

52. Sahara Mart, Inc. v. Ind. Dep't of State Revenue, 114 N.E.3d 36, 47-48 (Ind. T.C. 2018).

53. Id. at 47 .

54. Id. at 48 .

55. IND. R. EVID. 201(a).

56. IND. R. EvID. 201(b).

57. Henthorn v. Doe, 1 Blackf. 157, 164 (Ind. 1822); State v. Louisville \& N. R. Co., 96 N.E. 340, 344 (Ind. 1911) (quoting Munn v. Burch, 25 Ill. 21, 24 (1861)) (quotation marks omitted).

58. IND. CODE §§ 34-38-4-1 et seq. (2019); In re Paternity of P.R., 940 N.E.2d 346, 349 (Ind. Ct. App. 2010); see, e.g., Tavake v. State, 131 N.E.3d 696, 702 (Ind. Ct. App.) (taking judicial notice of California Penal Code), trans. denied, 134 N.E.3d 1021 (Ind. 2019).

59. IND. R. EvID. 201(a).

60. L.H. v. Ind. Dep't of Child Servs. (In re D.H.), 119 N.E.3d 578, 583 n.10, reh'g granted, 122 N.E.3d 832 (Ind. Ct. App.), trans. denied, 130 N.E.3d 1145 (Ind. 2019).

61. Id. at 589 .

62. Id. at 585 .

63. Hickingbottom v. State, 121 N.E.3d 648, 654 (2019). 
the country in assessing the distance between an RV dealership and locations throughout the United States and Canada ${ }^{64}$ the date on which Super Bowl LI occurred ${ }^{65}$ and adoption decrees. ${ }^{66}$

Another common area for judicial notice, "records of a court of this state," also saw multiple invocations at the appellate level. In Song v. Iatarola, the Indiana Court of Appeals took notice of the underlying trial transcript, accessed through the Odyssey system. ${ }^{68}$ Another action saw the court of appeals permit judicial notice of a dismissal order in a prior action undergirding a motion to dismiss ${ }^{69}$ K.H. v. Cochran presented a challenge to whether a trial court exceeded the permissible bounds of judicial notice by noticing certain records from a CHINS proceeding. ${ }^{70}$ Finding that the request below had merely been to take judicial notice of the record, not the facts contained therein, the court of appeals found no reversible error in the trial courts use of notice. ${ }^{71}$

Another topic of focus for the Indiana Court of Appeals was at what procedural juncture judicial notice is permissible. The court reminded parties that judicial notice is appropriate in motions pursuant to Trial Rules $12(\mathrm{~B})(6),{ }^{72}$ $12(\mathrm{C}),{ }^{73}$ and $56 .^{74}$ Similarly, because judicial notice may be taken "at any stage of the proceeding," ${ }^{75}$ it is appropriate to take judicial notice on appeal, and it may be invoked through a specific request in an appellate brief. ${ }^{76}$ Nevertheless, simply asking a court to take judicial notice is not alone sufficient, and notice may be

64. Richardson's RV, Inc. v. Ind. Dep't of State Revenue, 112 N.E.3d 192, 198 n.11 (Ind. 2018).

65. Mickens v. State, 115 N.E.3d 520, 521 n.1 (Ind. Ct. App. 2018), trans. denied, 123 N.E.3d 139 (Ind. 2019).

66. Walker v. Knight, 119 N.E.3d 573, 576 n.4, reh'g granted in part and denied in part, 120 N.E.3d 1157 (Ind. Ct. App.), trans. denied, 130 N.E.3d 1136 (Ind. 2019).

67. IND. R. EvID. 201(b)(5).

68. 120 N.E.3d 1110, 1116 n.2 (Ind. Ct. App.), trans. denied, 134 N.E.3d 1014 (Ind. 2019). The same result was reachable absent judicial notice by operation of Indiana Appellate Rule 27. Id. ("Ind. Appellate Rule 27 (providing that the 'Record on Appeal . . consist[s] of the Clerk's Record and all proceedings before the trial court ... whether or not transcribed or transmitted to the Court on Appeal').").

69. Moss v. Horizon Bank, N.A., 120 N.E.3d 560, 563-64 (Ind. Ct. App. 2019).

70. 116 N.E.3d 504, 512 (Ind. Ct. App. 2018), trans. denied, 123 N.E.3d 144 (Ind. 2019).

71. Id.

72. Moss, 120 N.E. $3 \mathrm{~d}$ at 563.

73. Hendricks Cty. v. Green, 120 N.E.3d 1118, 1122 (Ind. Ct. App.), trans. denied, 130 N.E.3d 1146 (Ind. 2019).

74. IND. R. TRIAL P. 56(C) ("At the time of filing the motion or response, a party shall designate to the court all parts of pleadings, depositions, answers to interrogatories, admissions, matters of judicial notice, and any other matters on which it relies for purposes of the motion."); see, e.g., Walker v. Knight, 119 N.E.3d 573, 575, reh'g granted in part and denied in part, 120 N.E.3d 1157 (Ind. Ct. App.), trans. denied, 130 N.E.3d 1136 (Ind. 2019).

75. IND. R. EvID. 201(d).

76. Hickingbottom v. State, 121 N.E.3d 648, 654 (Ind. Ct. App. 2019). 
denied if the facts for which notice have been requested are not relevant to the court's determination. ${ }^{77}$

\section{RELEVANCY \& ITS LIMITS: RULES 401 THROUGH $413^{78}$}

\section{A. Rules 401 \& 402: What is and is Not Relevant}

Rule 402 establishes that relevant evidence is generally admissible and irrelevant evidence is not. "Rule 401 provides that evidence is relevant if it has any tendency to make a fact more or less probable than it would be without the evidence and the fact is of consequence in determining the action." ${ }^{\circ 0}$ There are instances when the relevance of evidence is patently obvious, such as "[t]estimony that, if true, would exonerate one man and implicate another." Other circumstances are significantly less clear.

In Tunstall v. Manning, the Indiana Supreme Court observed that past licensure probation of an expert witness who offers a diagnosis of a person's injuries is relevant evidence to assess the credibility of the witness's medical opinion. ${ }^{82}$ The Indiana Tax Court also addressed the issue of whether evidence passed the basic threshold of relevance established by Rule $401 .^{83}$ The court concluded that evidence showing a business sold alcohol on Sundays, maintained inaccurate records and fake invoices, had its majority owner skimming cash from the company, and paid individuals in cash were relevant "because they will affect the probability of two consequential facts: whether [the business] operated using volunteers not employees and whether it destroyed rather than sold certain alcohol." ${ }^{84}$

Likely the most notable decision from the survey period addressing relevance built upon the 2017 opinion Sims v. Pappas, wherein the Indiana Supreme Court determined that "a drunk driver's prior alcohol-related driving convictions" were relevant to the question of whether the driver should be subject to punitive

77. Marion Cty. Assessor v. Stutz Bus. Ctr., LLC, 132 N.E.3d 85, 90-91 (Ind. T.C. 2019).

78. Although not addressed in this survey, shortly after the close of the survey period, the Indiana Supreme Court approved a non-substantive amendment to Rule 412(c)(2), which became effective on January 1, 2020. Order Amending Ind. Rules of Court, No. 19S-MS-41, 2019 Ind. LEXIS 938, at *41 (Ind. Dec. 19, 2019).

79. IND. R. EVID. 402.

80. Rivera v. State, 132 N.E.3d 5, 12 (Ind. Ct. App. 2019), trans. denied, 141 N.E.3d 16 (Ind. 2020).

81. Bedolla v. State, 123 N.E.3d 661, 668 (Ind. 2019) (citing IND. R. EvID. 401).

82. 124 N.E.3d 1193, 1198 (Ind. 2019). Notably, the majority of the panel for the Indiana Court of Appeals suggested that "an expert's past disciplinary history" may not be relevant. Tunstall v. Manning, 107 N.E.3d 1093, 1099 (Ind. Ct. App. 2018) (“Clearly, an expert's past disciplinary history is, if at all, not as relevant as the expert's current probationary status." (emphasis added)), trans. granted and opinion vacated, 124 N.E.3d 1193 (Ind. 2019).

83. Sahara Mart, Inc. v. Ind. Dep't of State Revenue, 114 N.E.3d 36, 48 (Ind. T.C. 2018).

84. Id. 
damages but not relevant to calculating an injured person's compensatory damages. ${ }^{85}$ Clayton v. Smith, from the Indiana Court of Appeals, addressed a similar circumstance, wherein a severely intoxicated driver collided with a tree, rendering a passenger quadriplegic. ${ }^{86}$ During the trial, the defendant "testified that both he and [the plaintiff] had driven while intoxicated on some prior occasions." ${ }^{" 87}$ Despite the defense arguing that the "testimony had "opened the door' to evidence of [the plaintiff]'s criminal history," the defendant was not permitted to introduce evidence of the plaintiff's prior "convictions, one of which was alcohol-related and two of which were allegedly committed while . . under the influence of alcohol." ${ }^{88}$ The defendant "argued the criminal history was admissible to show [the plaintiff]'s state of mind and was evidence of his habit. $[\mathrm{He}]$ also argued that the criminal history was relevant to damages, specifically, lost wages, and to punitive damages. $"{ }^{\circ 9}$

The court acknowledged that Sims left open the question of relevance beyond punitive damages..$^{90}$ The court rejected the argument that the "criminal history was relevant to "throw light on [plaintiff's] state of mind," because "the proximate cause of [the plaintiff's] injuries was not in dispute." "91 Nor was the evidence relevant to the question of reasonable care since the defendant had "admitted some fault but stopped short of conceding that he had greater fault than [the plaintiff] and non-party [restaurant]." ${ }^{.92}$ Because neither proximate cause nor reasonable care were contested to the jury, any relevance the criminal history may have had was nonexistent at trial. ${ }^{93}$ That left the court with a single potential avenue for admitting the plaintiff's criminal history:

[W] hether [the plaintiff]'s prior convictions might constitute "state of mind" evidence relevant to the jury's apportionment of fault under the unique circumstances of this case. We are not so persuaded. Arguably, one who had been criminally punished in the past and was actively on probation would be motivated to avoid drunk driving and might insist

85. Clayton v. Smith, 113 N.E.3d 693, 699-701 (Ind. Ct. App. 2018) (discussing Sims v. Pappas, 73 N.E.3d 700, 705-07, 709 (Ind. 2017)), trans. denied, 123 N.E.3d 142 (Ind. 2019). For a discussion of Sims, see Colin E. Flora, 2017 Developments in Indiana Evidentiary Practice, 51 IND. L. REV. 1049, 1056-57 (2018) [hereinafter 2017 Survey].

86. Id. at 697 .

87. Id. at 698-99.

88. Id. at 699 .

89. Id.

90. Id. at 700 (quoting Sims, 73 N.E.3d at 706 n.5 ("Amicus curiae Indiana Trial Lawyers Association contends evidence of prior convictions is also relevant on the question of reasonable care and proximate cause, both of which are implicated in determining liability for a negligence claim. The parties do not explore this issue likely because liability was conceded. In similar fashion we decline to explore this issue as well. Instead we leave it open for another day.")).

91. Id.

92. Id.

93. Id. 
that another person drive instead. However, there is simply no evidence that [the plaintiff] did so insist. His criminal history was not relevant to a fact "of consequence in determining the action." $" 94$

\section{B. Rules 403 \& 404: Character Evidence, Prior Bad Acts \& Excluding Prejudicial Evidence}

Despite Rule 402's general pronouncement that relevant evidence is admissible, that rule may be overridden by a host of other sources, including Rule 403. ${ }^{95}$ By operation of Rule 403, even relevant evidence may be excluded "if its probative value is substantially outweighed by a danger of one or more of the following: unfair prejudice, confusing the issues, misleading the jury, undue delay, or needlessly presenting cumulative evidence." 96 Thus, even once a court has found evidence to be relevant, it may still need to turn to the balancing test of Rule 403, as the Indiana Supreme Court did in Tunstall v. Manning. ${ }^{97}$ Having found the past licensure probation of an expert witness in a personal-injury matter relevant to the expert's credibility, ${ }^{98}$ the court assessed the probative value of the evidence, finding: "Here, the probative value of the licensure-probation evidence outweighed any of Rule 403's dangers. [The expert] was the only medical expert to testify on [plaintiff]'s behalf, and his medical license was placed on probation only a few months after he first examined [plaintiff]." 99

Another decision providing a useful example to practitioners, though breaking no new ground on Rule 403, ${ }^{100}$ came from the Indiana Court of Appeals in Saintignon v. State. ${ }^{101}$ There, the court affirmed the use of photographs at trial depicting the criminal defendant's tattoos while attempting to show a bruised bicep. ${ }^{102}$ The bruise was one of numerous injuries to the defendant, which, the court reasoned, were relevant to show that he was more likely the man who committed a murder. ${ }^{103}$ The defense argued that showing the tattoos was prejudicial because they were Aryan Brotherhood tattoos and the prosecution had agreed to not admit evidence of his membership in the group. ${ }^{104}$ "Because none of the tattoos clearly denote the Aryan Brotherhood" and the prosecution "did not present any testimony identifying or explaining the significance of [the] tattoos,"

94. Id. (quoting IND. R. EvID. 401).

95. IND. R. EvID. 402(d); IND. R. EvID. 403.

96. IND. R. EvID. 403.

97. 124 N.E.3d 1193, 1198 (Ind. 2019).

98. Id.

99. Id.

100. See, e.g., Garrett v. Knight, No. 1:16-cv-03233-JMS-DML, 2019 U.S. Dist. LEXIS 88737 , at *17-18 (S.D. Ind. May 28, 2019) (analyzing prejudice in admission of photographs under Indiana Evidence Rule 403).

101. 118 N.E.3d 778, 790 (Ind. Ct. App.), trans. denied, 124 N.E.3d 46 (Ind. 2019).

102. $I d$.

103. Id.

104. Id. 
the prejudice, "if any," was minimal and did not substantially outweigh the probative value. ${ }^{105}$

Although Rule 403 generally focuses on the probative value of a specific piece of evidence or an individual's testimony, such as the professional discipline in Tunstall and the photographs in Saintignon, it can also come into play when multiple witnesses are called to provide repetitive testimony of out-of-court statements from a witness who has testified to the same statements in court. ${ }^{106}$

[I]n light of a proffered non-hearsay purpose, exclusion might not be warranted where there is a mere isolated reference to an assertion. However, as additional testimony about the assertion "beats the drum," there is increasing danger the jury will use the testimony for an improper purpose. For example, the jury might use the testimony as proof of the matter asserted. Or, the jury could treat the repetitive testimony as a form of vouching for the credibility of the declarant. As to the latter risk, this type of problematic vouching is not the blatant type prohibited by Evidence Rule 704(b) - where a witness directly opines about "the truth or falsity of allegations" or "whether a witness has testified truthfully." Rather, the risk is insidious. That is, the repeated references might eventually inundate the jury, leading them toward an inference that witnesses are vouching for the credibility of the declarant. ${ }^{107}$

The court of appeals, however, declined to determine whether the testimony in Kress v. State ran afoul of Rule 403, instead cutting to the chase and ruling that any error in the admission was harmless, noting that the victim testified first, providing specific details, while the other "witnesses gave only general testimony about the existence of allegations." 108

Often working hand-in-glove with Rule 403 is Rule 404, which sets the boundaries on evidence of a person's character or prior bad acts in order to prove or show "that on a particular occasion the person acted in accordance with the character or trait." 109 Broken into two subdivisions, "Rule 404(a) prohibits using evidence of a defendant's "character or character trait" and "Rule 404(b) prohibits the use of a defendant's 'crime, wrong, or other act." ${ }^{110}$ The rule derives from "a foundation of our system of jurisprudence [] that the State may not punish a person for his character. ${ }^{111}$ It shields persons - particularly, criminal

105. Id.

106. Kress v. State, 133 N.E.3d 742, 747 (Ind. Ct. App.), trans. denied, 138 N.E.3d 957 (Ind. 2019).

107. Id. (citations omitted).

108. Id a a 747-48. The court of appeals took a similar approach in Maffett v. State, opting to forego balancing before reaching the determinative conclusion that any error was harmless. 113 N.E.3d 278, 284-85 (Ind. Ct. App. 2018) (evidence of handgun ammunition found in apartment not sufficiently prejudicial despite no handgun found).

109. IND. R. EvID. 404(a)(1) \& (b)(1).

110. Maffett, 113 N.E.3d at 283 (quoting IND. R. EvID. 404(a)(1) \& (b)(1)).

111. Abd v. State, 121 N.E.3d 624, 630 (Ind. Ct. App.), trans. denied, 129 N.E.3d 781 (Ind. 
defendants - from "'the forbidden inference,' which is that a defendant is guilty of the alleged crime because the defendant possesses a bad character trait." 12

The analysis " "necessarily incorporates the relevancy test of Rule 401 and the balancing test of Rule 403." ${ }^{\prime 13}$ Accordingly, the first step is to determine if evidence is relevant; "[s]econd, the court must determine that the proponent has sufficient proof that the person who allegedly committed the act did, in fact, commit the act[;]" and, third, the court undergoes Rule 403 balancing. ${ }^{114}$ In Smith v. State, it was error to permit evidence that the defendant had been seen holding a pink handgun, fifteen days before he threatened the victim, and was arrested while in possession of a different handgun. ${ }^{115}$ The pink gun was not used for any permissible purpose under Rule 404(b)(2) and whatever probative value the pink gun may have had "was outweighed by unfair prejudice."116

Addressing an appellate challenge to character evidence in the absence of a contemporaneous objection, the Indiana Court of Appeals took an expansive view of Rule 404(b)(2)'s permissible use of prior bad acts to show motive in $A b d v$. State. ${ }^{117}$ Affirming convictions for murder and robbery, the court rejected a challenge to admission of "character evidence related to [defendant]'s smoking habits, dirty apartment, prior bad acts, and aggressive attitude." ${ }^{118}$ Determining that such evidence may have come in to show motive, the court speculated:

It is conceivable that the State proffered evidence of [defendant]'s living habits and attitude to demonstrate why he wanted to rob and murder [victim] in the first place. Due to his dire financial straits and poor living habits, [defendant] had the motive and intent to rob someone close to him whom he knew was financially successful. Evidence of [defendant]'s poor living conditions reflected his inability to maintain a clean home and his desire to rob someone else for wealth. After all, as the State points out, [defendant and his father] were able to secure better housing, pay off their debts, and improve their lives following [the] murder. ${ }^{119}$

Motive was also a permissible conduit for admission of otherwise excludable evidence in Wilcoxson v. State. ${ }^{120}$ The evidence at issue was that the defendant had fired a gun at a SWAT team attempting to take him into custody. ${ }^{121}$ The act was particularly noteworthy because the charges against him were for "two

2019).

112. Maffett, 113 N.E.3d at 283.

113. Id. (quoting Sanders v. State, 704 N.E.2d 119, 123 (Ind. 1999)).

114. Smith v. State, 116 N.E.3d 1107, 1115 (Ind. Ct. App. 2018), trans. denied, 127 N.E.3d 229 (Ind. 2019).

115. Id. at 1116 .

116. Id.

117. 121 N.E.3d 624, 630 (Ind. Ct. App.), trans. denied, 129 N.E.3d 781 (Ind. 2019).

118. Id. at 630 .

119. Id.

120. 132 N.E.3d 27, 30-32 (Ind. Ct. App.), trans. denied, 138 N.E.3d 963 (Ind. 2019).

121. Id. at 30-31. 
counts of attempted murder and one count of criminal recklessness for shooting up two police stations in Indianapolis." 122 The court of appeals affirmed admission on the basis of motive and showing consciousness of guilt. ${ }^{123}$ As to motive, the court found that "firing a gun when police went to arrest him tends to prove that he harbors significant hostility toward police. That hostility, in turn, strongly suggests a motive for the [prior] shootings." 124 In opposition to consciousness of guilt, the defendant argued that he had two other warrants he was seeking to avoid arrest from, "[b]ut the fact that [he] might have had a consciousness of guilt with regard to other conduct does not mean that he did not also have a consciousness of guilt with regard to the [charged] shootings." 125 The court of appeals further found the evidence passed Rule 403 balancing, noting that the trial court had limited the prosecution to only showing that defendant fired a gun, not "that he shot at the officers." 126

Again, motive proved the mechanism for admitting prior bad acts in Thevenot v. State. ${ }^{127}$ There, the defendant proclaimed his motive-vengeance for a prior conviction of domestic battery - while committing domestic battery, announcing, "[S]he "throwed [sic] him in jail for six months, so he was going to beat six months." "28 Since the declaration "was the motive that [defendant] himself provided as he committed the crime," it squarely fit the motive exception of Rule 404(b)(2). ${ }^{129}$

Rule 404(b) also received the attention of the Indiana Supreme Court in assessing the use of prior bad acts to rebuff a claim of accident: In Fairbanks $v$. State, stemming from prosecution for the murder of an infant by suffocation, the state admitted evidence of prior instances in which the defendant used a pillow to stop an infant from crying. ${ }^{130}$ The key question turned on whether the state may admit evidence in opposition to an accident defense before the defendant asserts the defense. ${ }^{131}$ After a thorough analysis of analogous caselaw and scholarship on Rule 404(b)'s application to intent defenses, the court established two avenues by which "the State may offer other-bad-acts evidence of lack of accident . . . : (1) the State had 'reliable assurance' that an accident defense would be raised, or (2) the defendant placed accident at issue at trial." 132 Applying that approach, the court affirmed admission of the pillow evidence because the state had "reliable assurance' that [the defendant] would raise an accident defense, derived from his

122. Id. at 28 .

123. Id. at 31-32.

124. Id. at 31 .

125. Id.

126. Id. at 32 .

127. 121 N.E.3d 679, 684-85 (Ind. Ct. App. 2019).

128. Id. at 685 (alterations in original).

129. Id.

130. 119 N.E.3d 564, 566 (Ind.), cert. denied, 140 S. Ct. 198 (2019).

131. $I d$. at 569 .

132. Id. at 571 (footnote omitted). 
pretrial statements to police and from his news interviews before trial."133

In Maffett $v$. State, the court of appeals provided an important perspective on the reach of Rule 404(b)'s exclusion of prior bad acts. ${ }^{134}$ Rejecting a challenge to the use of a video recording in which the defendant discussed the reasoning for maintaining firearms in his residence as a need for protecting himself in light of what he does, ${ }^{135}$ the court determined that not all bad acts "implicate Evidence Rule 404(b)." ${ }^{136}$ Even though "the video may create an inference [defendant] was engaged in activities for which a gun was required for protection," a "mere inference" is insufficient for exclusion under Rule 404(b). ${ }^{137}$ As to the content of the video, the language was too vague for the court to "say it demonstrates a bad act that could be prejudicial." 138

Just as "mere inferences" are not enough for Rule 404(b), neither are references that are "fragmentary at best." 139 The mere mention by a trooper on cross-examination that he had not spoken with the defendant because the defendant "had been arrested on another offense through a separate county," was not reversible error because "the statement did not disclose the reason for the arrest, whether charges had been filed pursuant to that arrest, or whether the arrest resulted in a conviction." 140

Rivera $v$. State provided another example of an often narrow view toward Rule 404(b) exclusions. ${ }^{141}$ There, among other issues, the defendant was crossexamined over receiving disability benefits. ${ }^{142}$ The cross-examination was deemed permissible because the defendant had "testified during direct examination that he worked and landscaped to pay bills," and "[t]he cross examination ... explored the dishonesty associated with working while receiving disability checks and was proper impeachment evidence and not a violation of Ind. Evidence Rules 403 and 404(b)."143

It is not always the prosecution in criminal matters that must contend with the exclusionary aspects of Rule 404(b). In Saintignon, the defendant relied on a theory that a different man committed the murder. ${ }^{144}$ Since the other man "was

133. Id. at 572 .

134. 113 N.E.3d 278, 283 (Ind. Ct. App. 2018).

135. Id. The two statements at issue in the video were: "1. Detective DeYoung's statement to Maffett that, 'so if you got a gun, like a shotgun, it's for protection, you're not trying to shoot the police or nothing like that, if it's like you said, someone rolls up three deep because of what you do, that you own a shotgun to protect yourself.' [] 2. Maffett's statement to Detective DeYoung that 'I got a whole box of 9's because a MF'r come wanting a 3, I said cool give me the shells.'" Id.

136. Id. (citing Dixson v. State, 865 N.E.2d 704, 712 (Ind. Ct. App. 2007)).

137. Id.

138. Id.

139. Gridley v. State, 121 N.E.3d 1071, 1077 (Ind. Ct. App. 2019).

140. Id.

141. 132 N.E.3d 5, 12-13 (Ind. Ct. App. 2019), trans. denied, 141 N.E.3d 16 (Ind. 2020).

142. Id. at 10 .

143. Id. at 12 .

144. 118 N.E.3d 778, 786 (Ind. Ct. App.), trans. denied, 124 N.E.3d 46 (Ind. 2019). 
declared unavailable as a witness, [defendant] sought to have [the man's ex-wife] testify that she had procured a protective order against [him] because he had once held knives to her throat and threatened to decapitate her." 145 The court of appeals affirmed exclusion of that testimony, recognizing that it "is the very type of evidence that Indiana Evidence Rule 404(b) is meant to exclude." ${ }^{146}$ While the defendant "had a right to present a defense, . . . that defense was still required to comport with the rules of evidence," which the proffered testimony did not. ${ }^{147}$

In a similar posture, Newland $v$. State saw a defendant attempting to point a finger at another for the crime of unlawfully drawing a $\$ 300$ check. ${ }^{148} \mathrm{In}$ attempting to do so, the defendant sought to admit evidence of a prior conviction of that person for theft from his place of employment. ${ }^{149}$ The court acknowledged a modern trend of "apply[ing] Rule 404(b) to evidence about the bad acts of nonparties. Under what has come to be called 'reverse 404(b),' courts have held that 'a defendant can introduce evidence of someone else's conduct if it tends to negate the defendant's guilt." 150 Nevertheless, the court determined that the intended use was not permissible; instead, the court believed, defendant's "real motivation" was not to show "motive, plan, or identity," but, rather, "for the sole purpose of creating the forbidden inference, namely, prior wrongful conduct in similar circumstances suggest[ing] present guilt" of the other person. ${ }^{151}$

\section{Rule 405: When Character is an Essential Element}

"If character evidence falls under one of the exceptions in Rule 404(a), . . . Evidence Rule 405 establishes the methods by which it may be proved." 152 Indiana 405(b) further provides “[w] hen a person's character or character trait is an essential element of a charge, claim, or defense, the character or trait may also be proved by relevant specific instances of the person's conduct." ${ }^{153}$ In concluding that the doctrine of claims preclusion applies in CHINS proceedings "to bar a repeated filing of a CHINS petition based on evidence that could have been produced in the first filing," the Indiana Supreme Court looked to the role of character evidence in CHINS proceedings. ${ }^{154}$ The court observed "that when children are alleged to be CHINS under Indiana Code section 31-34-1-1 . . . a

145. $I d$.

146. Id.

147. Id.

148. 126 N.E.3d 928, 930 (Ind. Ct. App. 2019).

149. Id. at $931-32$.

150. Id. at 932 (quoting Garland v. State, 788 N.E.2d 425, 429 (Ind. 2003)) (internal citations omitted).

151. Id. at 932 .

152. Johnson v. State, 671 N.E.2d 1203, 1207 (Ind. Ct. App. 1996).

153. IND. R. EvID. 405(b).

154. V.B. v. Ind. Dep't of Child Servs. (In re Eq.W.), 124 N.E.3d 1201, 1205, 1210-11 (Ind. 2019). 
parent's character is a material issue in the proceeding." 155 In such actions, "Rule of Evidence 405(b) allows admission of specific instances of a parent's character because 'a parent's past, present, and future ability to provide sufficient care for his or her child forms the basis for a CHINS adjudication' and 'a parent's character is an integral part of assessing that ability." "156

\section{Rule 408: Compromise Offers \& Negotiations}

"It is axiomatic that . . . courts look with great favor upon the voluntary resolution of litigation through settlement." ${ }^{57}$ Assisting that perspective, Rule 408 acts to protect the freedom to work toward compromises by curtailing the subsequent use of negotiations. ${ }^{158}$ But Rule 408 is not a complete bar to use of settlement negotiations, provided that the use is for a purpose other than "to prove or disprove the validity or amount of a disputed claim or to impeach by a prior inconsistent statement or a contradiction ... such as proving a witness's bias or prejudice, negating a contention of undue delay, or proving an effort to obstruct a criminal investigation or prosecution." 159

A matter before the Indiana Tax Court provides a circumstance in which Rule 408 does not prohibit admission of information gained during settlement talks. ${ }^{160}$ Overruling a challenge based on Rule 408, the tax court found a brief's two references to exchanges at the parties' settlement conference were not impermissible uses for two reasons. ${ }^{161}$ The first reason is not particularly notable; in the court's view, the references were submitted simply to show the court that the Indiana State Department of Revenue had notified the petitioner of the Department's "recent discovery activities," which is not a prohibited purpose. ${ }^{162}$ The second reason is much more notable and surprising: the court found the assertions were not an attempt to introduce evidence at all because "the two references to the settlement conference were contained in the Department's brief, and as attorney statements, they do not constitute evidence."163

\section{PRIVILEGES: RULES $501 \& 502$}

Rules 501 and 502 build upon the various privileges recognized by common law and statutes. ${ }^{164}$ Although neither Rule 501 nor Rule 502 garnered much

155. Id. at 1210.

156. Id. Similarly, Indiana Code $\S 31-34-12-5$ "supports the . . position that a parent's prior acts are relevant to that parent's fitness at the time of a CHINS proceeding." Id.

157. Armstrong v. Bd. of Sch. Dirs., 616 F.2d 305, 312 (7th Cir. 1980).

158. ArcelorMittal Ind. Harbor LLC v. Amex Nooter, LLC, No. 2:15-cv-195-PRC, 2016 U.S. Dist. LEXIS 18211, at*12 (N.D. Ind. Feb. 16, 2016); IND. R. EvID. 408(a).

159. IND. R. EVID. 408(a), (b).

160. Sahara Mart, Inc. v. Ind. Dep't of State Revenue, 114 N.E.3d 36, 44-45 (Ind. T.C. 2018).

161. Id. at 45 .

162. Id.

163. Id.

164. IND. R. EvID. 501; IND. R. EvID. 502. 
attention during the survey period, Indiana courts had ample opportunity to address privileges ranging from attorney-client to insurer-insured privilege. Indeed, both privileges were at issue in Zurich American Insurance Company v. Circle Center Mall, $L L C .^{165}$ The action followed from the injury to a patron of the Circle Center Mall in Indianapolis, Indiana. ${ }^{166}$ This was not, however, a personalinjury action; rather, it was a claim by Circle Center for breach of contract against the company responsible for maintenance of escalators at the mall and the provider of its insurance policy, under which Circle Center was supposed to be named an additional insured. ${ }^{167}$ The issue on appeal arose from a discovery dispute in which the insurer and the company responsible for maintaining the escalators invoked multiple privileges to withhold production of documents. ${ }^{168}$

The court's analysis began by rejecting Circle Center's invitation to adhere to Delaware precedent and adopt the "the trial is the file" approach to claims for bad-faith denial of insurance coverage. ${ }^{169}$ Recognizing that Indiana previously "declined to adopt the position that the contents of a claims file in a bad-faithdenial-of-coverage case could not be protected by evidentiary privileges," the court transitioned to analyze application of the attorney-client and insurer-insured privileges. ${ }^{170}$ The latter privilege applies "where the policy of insurance requires the insurer to defend claims against the insured, [such that] statements from the insured to the insurer concerning an occurrence which may be made the basis of a claim by a third party are protected from disclosure." apply to prevent disclosure to Circle Center because Circle Center was an additional insured of the policy, not a third-party claimant. ${ }^{172}$

Attorney-client privilege proved the more viable avenue to resist disclosure. ${ }^{173}$ "The essential prerequisites to invocation of the privilege are to establish by a preponderance of the evidence: 1) the existence of an attorneyclient relationship and 2) that a confidential communication was involved." 174 One of five documents for which the privilege was asserted was not covered because it was a communication from a claims adjuster to the maintenance company's attorney, which is not "advice given by an attorney to a client." 175 The other four documents were protected by the privilege, but only by way of

165. 113 N.E.3d 1220, 1229-31 (Ind. Ct. App. 2018), trans. denied, 124 N.E.3d 53 (Ind. 2019).

166. Id. at 1223 .

167. Id. at $1223-24$.

168. Id. at 1227-31.

169. Id. at 1227-28 (citing Tackett v. State Farm Fire \& Casualty, 558 A.2d 1098, 1103 (Del. Super. Ct. 1988)).

170. Id. at $1228-31$.

171. Id. at 1230 (quoting Richey v. Chappell, 594 N.E.2d 443, 447 (Ind. 1992)) (internal quotation marks omitted).

172. Id. at 1230-31.

173. Id. at $1229-30$.

174. Id. at 1230 (citation and formatting omitted).

175. Id. 
invocation of a corollary privilege. ${ }^{176}$ Each was prepared by the maintenance company's attorney and then shared with the insurer. ${ }^{177}$ " $[\mathrm{T}]$ he general rule [is] that the attorney-client privilege is waived when privileged information is disclosed to a third party." 178 But the privilege remains when the common-interest privilege applies. ${ }^{179}$ It "is 'an extension of the attorney-client privilege' that 'permits parties whose legal interests coincide to share privileged materials with one another in order to more effectively prosecute or defend their claims." "180 Given the shared interest between the maintenance company and the insurer to not indemnify Circle Center, their interests were "sufficiently aligned for the time being" to invoke "the common-interest extension to the attorney-client privilege." $" 181$

Indiana's attorney-client-privilege law also drove several decisions of federal courts both within and beyond Indiana's borders. Ranburn Corp. v. Argonaut Great Central Insurance Company presented a complicated test to attorney-client privilege. ${ }^{182} \mathrm{~A}$ decade-long fight over insurance coverage saw the insured retain its own counsel, after its insurer opted to permit the insured to select its own legal representation under a reservation of rights. ${ }^{183}$ Later in the litigation, the insurer dropped the reservation of rights, fully assuming the defense. ${ }^{184}$ In a related action, the insurer sought to obtain documents from the insured that related to communications with the counsel that had been selected prior to the insurer dropping the reservation of rights, who remained counsel after the insurer did so. ${ }^{185}$ An initial determination was whether, upon dropping the reservation of rights, the insurer became a co-client of the insured's legal counsel. ${ }^{186}$

Finding no controlling decision, the United States District Court for the Northern District of Indiana "predict[ed] that the Indiana Supreme Court would decide that the insurance company does not automatically become a co-client of its insured when a reservation of rights is withdrawn." ${ }^{87}$ As such, the analysis turned entirely on whether an independent relationship existed so as to form an attorney-client relationship between the insurer and legal counsel. ${ }^{188}$ The court determined that no such relationship was created because the counsel "did not consent to forming an attorney-client relationship with [the insurer], [and] did not

176. $I d$.

177. Id.

178. Id. (quoting Groth v. Pence, 67 N.E.3d 1104, 1119 (Ind. Ct. App. 2017)) (quotation marks omitted, alterations in original).

179. Id.

180. Id. (quoting Groth, 67 N.E.3d at 1119).

181. Id.

182. No. 4:16-cv-88-RL-PRC, 2018 U.S. Dist. LEXIS 225199 (N.D. Ind. Nov. 26, 2018).

183. Id. at $* 3$.

184. Id.

185. Id.

186. Id. at $* 6-14$.

187. Id. at $* 10$.

188. Id. at *10-14. 
represent [it] in the" related litigation. ${ }^{189}$ Accordingly, the insurer could not compel discovery of communications between the insured and its counsel, nor could it compel discovery of communications between the counsel and an environmental consultant retained for the related litigation. ${ }^{190}$

The United States District Court for the Western District of Texas also faced the challenge of applying Indiana's attorney-client privilege. ${ }^{191}$ Having found that "Indiana privilege law applies because both parties assert Indiana state law claims and Indiana state law provides the rule of decision for the parties' underlying claims, $" 192$ the court set to determine whether the privilege had been waived. ${ }^{193}$ "[T]he asserting party may implicitly waive privilege if it 'relies specifically on advice of counsel to support a claim or defense and intends to prove that claim or defense using privileged communications." ${ }^{194}$ The court ruled that waiver had not occurred when the party asserted a lack of sufficient knowledge on whether to rescind a bond. ${ }^{195}$ "[T] $[\mathrm{T}$ he mere fact that some attorney-client communications might bear on the issue of the . . knowledge does not mean the [party] has waived privilege as to all communications touching on [it]'s knowledge and intent." 196

Other guidance into Indiana's privilege law from beyond Indiana courts came from the Maryland Court of Special Appeals. ${ }^{197}$ Addressing whether spousal privilege may be pierced if the marriage is shown to be a sham, the court noted that while "Indiana has refused to create a judicial exception, . . . it has not foreclosed the possibility that a sham marriage "may amount to a fraud on the court." 198

Another privilege gaining the attention of both Indiana's state and federal courts is work-product privilege. In a short mention, the Seventh Circuit acknowledged an important point in applying the doctrine to criminal proceedings: "Indiana's work-product privilege does not override the Brady [v. Maryland] obligations of its police and prosecutors." 199 A more substantive analysis of Indiana's work-product privilege was presented to the Indiana Court of Appeals, seeking to interpret the meaning of "in anticipation of litigation."200

189. $I d$. at $* 14$.

190. Id. at *14-19.

191. Sw. Marine \& Gen. Ins. Co. v. NCUA Bd., No. AU-17-CA-00367-SS, 2018 U.S. Dist. LEXIS 203684, at *6-8 (W.D. Tex. Nov. 30, 2018).

192. Id. at $* 5$.

193. Id. at *6-8.

194. Id. at *6 (quoting Franklin United Methodist Home, Inc. v. Lancaster Pollard \& Co., 909 F. Supp. 2d 1037, 1047 (S.D. Ind. 2012)).

195. Id. at *7.

196. Id.

197. Wilson v. State, 213 A.3d 655, 666 (Md. Ct. Spec. App. 2019).

198. Id. (quoting Glover v. State, 836 N.E.2d 414, 19 (Ind. 2005)).

199. Goudy v. Cummings, 922 F.3d 834, 839 (7th Cir. 2019).

200. Zurich Am. Ins. Co. v. Circle Ctr. Mall, LLC, 113 N.E.3d 1220, 1228 (Ind. Ct. App. 2018) (quoting Ind. R. Trial P. 26(B)(3)) (quotation marks omitted), trans. denied, 124 N.E.3d 53 
"A document is gathered in anticipation of litigation if it can fairly be said that the document was prepared or obtained because of the prospect of litigation."201 Although the documents at issue squarely met almost all of the dictates of workproduct privilege, a question of application remained because the documents were prepared in anticipation of different litigation than the case in which the privilege was asserted. ${ }^{202}$ Finding the privilege "does not specifically require that the material had to be prepared for litigation between the party seeking discovery and the party resisting it," the court determined work product created in anticipation of prior litigation remains privileged in subsequent litigation. ${ }^{203}$

The privilege against self-incrimination, enshrined in the Fifth Amendment, also garnered substantial attention from Indiana's state and federal courts.

The Fifth Amendment to the U.S. Constitution, made applicable to the states through the Fourteenth Amendment, provides that no person shall be compelled in any criminal case to be a witness against himself. "[A] witness who desires the protection of the privilege must claim it at the time he relies on it." "[N]o ritualistic formula is necessary in order to invoke the privilege" against self-incrimination. Rather, the witness must only put the interrogating official "on notice [that he] intends to rely on the privilege." The express invocation requirement gives courts tasked with evaluating a Fifth Amendment claim a contemporaneous record establishing the witness's reasons for refusing to answer. ${ }^{204}$

Notable observations on this privilege, from the survey period, include: the privilege was not violated by testimony that the defendant told his mother that he was not going to talk to the police, because the statement made to the mother was not sufficient to invoke the privilege; ${ }^{205}$ "a witness' constitutional privilege against self-incrimination" does not depend "upon a judge's prediction of the likelihood of prosecution," but instead, "it is only where there is but a fanciful possibility of prosecution that a claim of fifth amendment privilege is not well taken;" 206 while neither the Supreme Court of the United States nor Indiana's appellate courts have decided whether post-arrest, pre-Miranda silence may be used substantively as evidence, ${ }^{207}$ if the criminal defendant ${ }^{208}$ has opened the door

(Ind. 2019).

201. Id. (internal citation and quotation marks omitted).

202. Id. at 1229.

203. Id.

204. Davis-Martin v. State, 116 N.E.3d 1178, 1193 (Ind. Ct. App.) (internal citations omitted, alterations in original), trans. denied, 124 N.E.3d 59 (Ind. 2019).

205. Id. at 1193-94.

206. Lacy v. Butts, 922 F.3d 371, 377 (7th Cir. 2019) (internal citations and quotation marks omitted, emphasis in original).

207. Kelly v. State, 122 N.E.3d 803, 806 (Ind. 2019) (citing Fletcher v. Weir, 455 U.S. 603, 607 (1982)) ("With regard to whether defendant's post-arrest, pre-Miranda silence can be used for impeachment purposes, the U.S. Supreme Court has held that it can be used.”).

208. The privilege does not protect negative inferences from silence in civil cases. M.K. v. Ind. 
to the evidence, it may be used, ${ }^{209}$ and a witness who pleads the Fifth and is then presented immunity in accordance with Indiana Code section 35-37-3-3 may be held in contempt, even if acting on advice of counsel, should he or she continue to refuse to testify. ${ }^{210}$

Two other important points regarding Indiana privileges were announced by the United States District Court for the Northern District of Indiana. First, the proprietary privilege announced by Delaware Chancery Courts has not been recognized by federal or Indiana state courts. ${ }^{211}$ And, second, although there is no privilege that protects personnel files from discovery, Indiana courts recognize important "public policy protecting the privacy rights of individuals with respect to sensitive personnel matters." 212

\section{WITNESSES: RULES 601 THROUGH 617}

\section{A. Rule 602: Personal Knowledge in Service of Process}

Unless testifying as an expert witness, all witness's testimony is confined to his or her "personal knowledge of the matter." 13 In a dissenting opinion for the Indiana Court of Appeals, Judge Paul Mathias instructed that an unsigned affidavit of service indicating service was made by a person other than the affiant necessarily fails to meet the threshold showing of testimony from personal knowledge. $^{214}$ The majority, due to the silence in the party's briefs regarding service of an alias summons, determined that service had been effectuated. ${ }^{215}$

Judge Mathias, on the other hand, would have found the lack of evidence in the record demonstrating service had been effected constituted a failure to satisfy the requirements of procedural due process. ${ }^{216}$ Although, as a dissent, Judge Mathias's opinion is not binding, ${ }^{217}$ it provides an important example of the need

Dep't of Child Servs., 6 N.E.3d 952, 957 (Ind. Ct. App. 2014) (“'A]lthough the refusal to testify in a civil case cannot be used against the one asserting the privilege in a subsequent criminal proceeding, the privilege against self-incrimination does not prohibit the trier of fact in a civil case from drawing adverse inferences from a witness' refusal to testify.").

209. Kelly, 122 N.E.3d at 807.

210. Tunis v. State, 129 N.E.3d 258, 262-65 (Ind. Ct. App.), trans. denied, 138 N.E.3d 946 (Ind. 2019).

211. Zimmer, Inc. v. Beamalloy Reconstructive Med. Prods., LLC, No. 1:16-cv-00355-TLSSLC, 2019 U.S. Dist. LEXIS 47539, at*32 n.9 (N.D. Ind. Mar. 21, 2019).

212. Balderas v. Target Corp., No. 2:17-cv-270-JEM, 2019 U.S. Dist. LEXIS 52333, at*3-4 (N.D. Ind. Mar. 27, 2019) (quoting Baker v. Town of Middlebury, 753 N.E.2d 67, 72 (Ind. Ct. App. 2001)) (quotation marks omitted).

213. IND. R. EvID. 602.

214. X.S. v. Ind. Dep't of Child Servs., 117 N.E.3d 601, 609-10 (Ind. Ct. App. 2018) (Mathias, J., dissenting).

215. Id. at 605-06.

216. Id. at 614 .

217. Save Our Sch. v. Fort Wayne Cmty. Schs., 951 N.E.2d 244, 248 (Ind. Ct. App. 2011). 
to attest to service based upon personal knowledge. ${ }^{218}$

\section{B. Rule 608: Prior Uncharged Professional Misconduct}

Rule 608(b) "makes extrinsic evidence, apart from criminal convictions permitted under Rule 609, inadmissible 'to prove specific instances of a witness's conduct in order to attack or support the witness's character for truthfulness." 219 In Tunstall v. Manning, the majority of the Indiana Supreme Court concluded that an expert's prior conduct resulting in a finding by the Medical Licensing Board that he "engaged in "fraud or material deception" by failing to disclose a pending criminal violation on his license renewal application and that he had failed to maintain controlled-substance dispensing records were barred by operation of Rule $608(\mathrm{~b}) .{ }^{220}$ Because the acts were not charged and convicted as criminal acts, they were "inadmissible to impeach the doctor."221

Justice Geoffrey Slaughter, alone in dissent, would have applied Rule 608(b) more narrowly than had the majority. ${ }^{222}$ While he agreed that the specific instances of the doctor's misconduct were properly excluded, Justice Slaughter contended "that [the] rule did not foreclose . . . impeaching the doctor with the fact of his prior discipline." ${ }^{, 23}$ Meaning, even though the jury could not learn of the "misconduct prompting the doctor's discipline," it should have been permissible for the jury to be informed that the doctor had twice been subject to professional discipline. ${ }^{224}$

\section{Rule 609: Impeachment by Evidence of a Criminal Conviction}

Rule 609 provides the parameters for the exception to Rule 608(b)'s prohibition on use of "specific instances of a witness's conduct in order to attack or support the witness's character for truthfulness." 25 Under Rule 609, a witness's prior criminal convictions may be used to impeach his or her testimony. ${ }^{226}$ Not all convictions may be used; rather, the crime is admissible "only if the crime committed or attempted is (1) murder, treason, rape, robbery, kidnapping, burglary, arson, or criminal confinement; or (2) a crime involving dishonesty or false statement, including perjury." ${ }^{227}$ If the conviction and the witness's release from confinement are more than ten years old, evidence of

218. "As a legal analyst, you must pay attention to dissents, especially those that are well reasoned.” Bryan A. Garner et Al., The LaW of Judicial Precedent 192 (2016).

219. Tunstall v. Manning, 124 N.E.3d 1193, 1199 (Ind. 2019) (quoting IND. R. EvID. 608(b)).

220. $I d$.

221. Id.

222. Id. at 1201 (Slaughter, J., dissenting).

223. Id.

224. Id.

225. IND. R. EvID. 608(b).

226. IND. R. Evid. 609(a); Clayton v. Smith, 113 N.E.3d 693, 699 n.4 (Ind. Ct. App. 2018), trans. denied, 123 N.E.3d 142 (Ind. 2019).

227. IND. R. EvID. 609(a). 
conviction is only admissible if: "(1) its probative value, supported by specific facts and circumstances, substantially outweighs its prejudicial effect; and (2) the proponent gives an adverse party reasonable written notice of the intent to use it so that the party has a fair opportunity to contest its use."228

The Indiana Supreme Court's decision in Tunstall v. Manning was not confined to the expert's professional discipline; the defense also sought to admit the reasons for his discipline, which included two misdemeanor convictions. ${ }^{229}$ Because the misdemeanor convictions were beyond the scope of Rule 609(a), they were deemed properly excluded. ${ }^{230}$

The Indiana Court of Appeals also had occasion to address Rule 609. ${ }^{231}$ A criminal defendant appealed his conviction for burglary because, he contended, the trial court erred in prohibiting him from cross-examining the state's witness regarding the specifics of the witness's prior conviction for theft. ${ }^{232}$ The witness had, in fact, testified during direct examination "that he had prior convictions for theft, conversion, and auto theft, and was currently in jail., ${ }^{233}$ As generally applied, Rule 609(a) limits use of convictions to the mere fact of the conviction, not the "circumstances surrounding the conviction." ${ }^{234}$ A party may open the door to more extensive examination if the testimony regarding the conviction left "the trier of fact with a false or misleading impression of the facts related." 235 The court of appeals determined the door was not opened to further inquiry because "[t]he State merely questioned him whether he had been convicted of theft in 2016, to which [the witness] responded affirmatively." 236 Absent some showing that the jury had been misled, there was no basis for further inquiry. ${ }^{237}$

An important point from the decision was the court's rejection of an attempt to invoke federal caselaw permitting more expansive use of a prior conviction:

Referencing federal case law, [the defendant] maintains that Evid. R. 609 "does not limit the use of evidence of prior convictions for purposes other than impeachment." Nevertheless, Indiana case law has consistently held that the applicability of Evid. R. 609 "is expressly limited to those circumstances where the evidence of the prior conviction is being offered [f]or the purpose of attacking the credibility of a witness." $" 238$

228. IND. R. EvID. 609(b).

229. 124 N.E.3d at 1198-99.

230. Id. at 1199.

231. Newland v. State, 126 N.E.3d 928, 931 (Ind. Ct. App. 2019).

232. Id. at 931.

233. Id. at 930 .

234. Id. at 931 .

235. Id. (internal citation and formatting omitted).

236. Id.

237. Id.

238. Id. (internal citations omitted); see Appellant's Brief at 8, Newland v. State, 126 N.E.3d 928 (Ind. Ct. App. 2019) (No. 19A-CR-95) (quoting Ricketts v. City of Hartford, 74 F.3d 1397, 


\section{Rule 611: Facilitating Testimony Through Leading Questions}

Rule 611(c) generally establishes that leading questions should be reserved for cross-examinations and examinations of hostile witnesses, not for direct examinations. ${ }^{239}$ But Rule 611(c)'s prohibition on use of leading questions on direct examination is not absolute. Instead, "[t]he rule is phrased in suggestive ('should not') rather than mandatory terms." ${ }^{240}$ Traditionally, trial courts are afforded a wide berth in deciding when to allow leading questions on direct examination, which means that reversals on the grounds of inappropriate use of leadings questions "are exceedingly rare." ${ }^{241}$

The propriety of leading questions was put to the test in Stinson v. State. ${ }^{242}$ At the time of trial, the victim of multiple stabbings was left in a condition in which he could only communicate using a tablet and by indicating "yes" or "no." ${ }^{243}$ Prior to his direct examination, the prosecution requested accommodation from the court to permit leading questions. ${ }^{244}$ Notably, the 1975 Advisory Committee Notes to Federal Rule of Evidence 611, on which Indiana's Rule 611 is based, recognized the appropriate use of leading questions to facilitate the testimony of an "adult with communication problems." ${ }^{245}$ Receiving no objection, the trial court permitted leading questions on direct of the witness. ${ }^{246}$

1412 (2d Cir. 1996) ("Fed. R. Evid. 608(b) does not pose a bar to admitting the tape on these grounds. That rule generally precludes proof by extrinsic evidence of 'specific instances of the conduct of a witness, for the purpose of attacking or supporting the witness' credibility, other than conviction of crime as provided in rule 609.' We have determined, however, that this rule does not operate to require the exclusion of impeachment evidence that demonstrates the witness' bias, as opposed to his character for untruthfulness.")).

239. IND. R. EVID. 611(c).

240. Michael H. Graham, Federal Practice and Procedure: Evidence $\S 6548$ (1992); accord United States v. Ajmal, 67 F.3d 12, 16 (2d Cir. 1995) ("the rule employs "words of suggestion, not command"'). Indiana Evidence Rule 611 is identical to Federal Rule of Evidence 611. 13B Robert L. Miller, JR., Indiana Practice: Courtroom Handbook on Indiana EVIDENCE 196 (2016-17 ed.).

241. Joseph W. Cotchett, Federal Courtroom Evidence $§ 611.4$ (5th ed. 2013).

242. 126 N.E.3d 915, 922-24 (Ind. Ct. App. 2019).

243. Id. at 922. Proving once again the Nostradamus-like skill of science-fiction writers to predict the future. Star Trek: The Menagerie, Part I (CBS television broadcast Nov. 17, 1966) (Captain Pike, horribly maimed in an accident, left able to communicate only through a light: one flash for "yes," two flashes for "no").

244. Stinson, 126 N.E.3d at 922 . The court of appeals considered the issue in spite of waiver because, "[w]hile the waiver doctrine advances important policies of judicial efficiency, mere expediency is not an appropriate appellate goal." (internal citation and quotation marks omitted).

245. FED. R. Evid. 611, Advisory Committee Notes (1975); accord United States v. Rodriguez-Garcia, 983 F.2d 1563, 1570 (10th Cir. 1993) (“According to the Advisory Committee Notes, a leading question may be asked of an adult witness with communication problems.").

246. Stinson, 126 N.E.3d at $922-23$. 
On appeal, the convicted defendant argued that the "testimony was the result of leading questions, and the State's questions were specifically crafted to mirror the testimony of prior witnesses." ${ }^{247}$ The court of appeals found no reversible error for two reasons. First, the witness's limited ability to communicate appropriately necessitated leeway on examination. ${ }^{248}$ And, second, the crucial testimony was not, in fact, educed by leading questions. ${ }^{249}$ That may strike some readers as peculiar, in light of a frequent misconception that a question is leading if it is susceptible to a yes-or-no answer. ${ }^{250}$ Instead, "[a] leading question is one that suggests the desired answer to the witness." ${ }^{251}$ Merely asking a question "susceptible of a simple negative or affirmative answer," is not a leading question unless it "take[s] the form of an assertion of fact which the witness was asked to verify." 252

In Stinson, the victim was first asked whether he had hurt himself. ${ }^{253} \mathrm{He}$ was then asked systematically whether each of three other persons known to have been present at the time the victim was stabbed had hurt him. ${ }^{254}$ After answering "No" with regard to two of the persons, the victim testified "Yeah" when asked whether the defendant hurt him. ${ }^{255}$ Because there were only four individuals, including the victim, who were known to have been present, the victim had confirmed that "he did not harm himself but knew who had attacked him," and the questioning provided the victim "the opportunity to identify any of the other three as the attacker," the questions were not leading. ${ }^{256}$

\section{E. Rule 615: Separation of Witnesses}

A routine part of Indiana trials, "Rule 615 allows litigants to move for

247. Id. at 923.

248. Id.

249. Id.

250. See Edward W. Cleary et al., McCormick on Evidence $§ 6$ (3d ed. 1984) ("It is sometimes supposed that a question which can be answered yes or no is by that fact marked as leading, and the beginner may seek refuge in the form of a neutral alternative ('State whether or not ...') to escape the charge of leading. But quite often the former kind will be. The whole issue is whether an ordinary man would get the impression that the question desired one answer rather than another."); see, e.g., Jeffrey A. Boyll, Note, Witness Explanations During Cross-Examination: A Rule of Evidence Examined, 58 IND. L.J. 361, 367 n.42 (1982) ("This question, asking whether certain facts are true and answerable with yes or no, is a classic example of the leading question.").

251. Stinson, 126 N.E.3d at 923 (internal citation and quotation marks omitted); accord Williams v. State, 733 N.E.2d 919, 922 (Ind. 2000).

252. Starks v. State, 325 N.E.2d 855, 857-58 (Ind. Ct. App. 1975).

253. 126 N.E.3d at 923 . There may have been some basis to conclude that the question of whether the victim hurt himself was leading since the prosecutor prefaced the question by stating, "This may seem like a silly question ...." Id. (internal formatting omitted).

254. $I d$.

255. $I d$.

256. Id. at 923-24. 
separation of witnesses so they cannot hear each other's testimony." ${ }^{257}$ Prior to adoption of the Indiana Rules of Evidence, "separation of witnesses [wa]s not required by statute, nor by any rule of the common law. When asked for, it [wa]s granted, not of right, but as a favor." 258 Rule 615 made exclusion of witnesses during trial proceedings mandatory, unless a witness falls into one of the three delineated categories of witnesses who cannot be excluded. ${ }^{259}$ Although Rule 615 merely requires "witnesses excluded [from trial proceedings] so that they cannot hear other witnesses" testimony," ${ }^{, 60}$ it is not uncommon for separation orders to bar "discussions of expected testimony among the witnesses." 261 That is precisely what happened in Spinks v. State. ${ }^{262}$

The issue in Spinks was whether a trial court erred by allowing three witnesses to testify on behalf of the prosecution, despite each witness having violated the separation order. ${ }^{263}$ On review, the Indiana Court of Appeals recognized that " $[t]$ he determination of the remedy for any violation of a separation order is within the discretion of the trial court." ${ }^{264}$ And, "in the absence of connivance or collusion by the party calling the witness, [a trial court] may permit the witness to testify." 265 At common law, it was presumed to be "an abuse of discretion to exclude witnesses for violations of a separation order when the party seeking to call the witness had no part in the violation of the order."266 Nevertheless, exclusion may be proper if the party relying on the witness is at fault for the violation or if exclusion of the testimony does not "directly affect the party's ability to present its case." ${ }^{267}$ Where a witness is not excluded, a remedy for the violation may be had in issuance of a contempt citation or by permitting the violation to be used for impeachment. ${ }^{268}$

The trial court acted well within its discretion by allowing the witnesses to testify and permitting cross-examination to address the violation of the order. ${ }^{269}$ Because the violation appeared not to have been intentionally caused by the prosecution and there was no request for a finding of contempt, the lack of any further punitive action was not a basis for reversal. ${ }^{270}$

Not all witnesses, however, can be excluded from hearing other witnesses'

257. Spinks v. State, 122 N.E.3d 950, 954 (Ind. Ct. App. 2019).

258. Miller v. State, 648 N.E.2d 1208, 1210 (Ind. Ct. App. 1995).

259. Hernandez v. State, 716 N.E.2d 948, 950 (Ind. 1999) (construing phrase "this rule does not authorize [excluding]" as prohibiting trial court from excluding certain witnesses).

260. IND. R. EVID. 615.

261. See, e.g., Spinks, 122 N.E.3d at 955.

262. Id.

263. Id. at $954-56$.

264. Id. at 955 .

265. Id. (internal citation and quotation marks omitted).

266. Id. (internal citation and quotation marks omitted).

267. Id. (quotation marks and citation omitted).

268. $I d$.

269. Id. at 955-56.

270. Id. 
testimony. ${ }^{271}$ Neither "a party who is a natural person" nor an officer or employee of a party that is not a natural person and who is designated by the party's attorney may be excluded. ${ }^{272}$ In criminal prosecutions, the state will often designate an investigating police officer as the state's representative. The Indiana Court of Appeals was confronted with what to do when the formal step of designating the officer is overlooked. ${ }^{273}$ Following a brief recess, an officer "sat at the prosecutor's table as the State presented its first few witnesses." 274 When the officer was called as a witness, the defense objected and moved to exclude the officer's testimony. ${ }^{275}$ The trial court denied the motion and overruled the objection, allowing the officer to testify. ${ }^{276}$ On review, the court of appeals found no abuse of discretion, recognizing that the officer was included on the State's witness list, sat at the prosecutor's table as if properly designated, and that there was no objection by the defense until the officer was called to testify. ${ }^{277}$ In the absence of any apparent attempt at "subterfuge" and the fact that the State could simply have designated him in accordance with Rule 615(b), the trial court was soundly within its discretion to permit the testimony. ${ }^{278}$

\section{F. Rule 617: What Constitutes a Custodial Interrogation?}

After two years of significant developments, ${ }^{279}$ Rule 617 saw only a single published decision addressing its reach, during the survey period. The rule "requires that statements made during custodial interrogations conducted in a place of detention in felony criminal prosecutions shall not be admitted against the defendant unless they have been recorded." ${ }^{280}$ Recent caselaw has primarily focused on whether an interrogation occurred "in a Place of a Detention." ${ }^{281}$ In Johnson v. State, however, the court of appeals focused on whether statements

271. IND. R. EVID. 615.

272. IND. R. EvID. 615(a)-(b). There is a third category of witness that may not be excluded embodied in subdivision (c) for "a person whose presence a party shows to be essential to presenting the party's claim or defense," which is most often applied to "expert witnesses or witnesses who summarize large amounts of information.” Hernandez v. State, 716 N.E.2d 948, 954 (Ind. 1999) (Boehm, J., dissenting).

273. Tavake v. State, 131 N.E.3d 696, 704-05 (Ind. Ct. App.), trans. denied, 134 N.E.3d 1021 (Ind. 2019).

274. Id. at 705 .

275. Id.

276. Id.

277. $I d$.

278. $I d$.

279. See 2017 Survey, supra note 85, at 1063-65; Colin E. Flora, 2018 Developments in Indiana Evidentiary Practice, 52 IND. L. REV. 715, 736-38 (2019) [hereinafter 2018 Survey].

280. Johnson v. State, 117 N.E.3d 581, 588 (Ind. Ct. App. 2018), trans. denied, 124 N.E.3d 41 (Ind. 2019).

281. Fansler v. State, 100 N.E.3d 250, 253-55 (Ind. 2018). 
were made during an interrogation. ${ }^{282}$ "Interrogation has been defined as a process of questioning by law enforcement officials which lends itself to obtaining incriminating statements." ${ }^{283}$ The boundaries of interrogation are not defined purely by express questioning; instead, "words or actions on the part of the police that they know are reasonably likely to elicit an incriminating response from the suspect" may also constitute an interrogation. ${ }^{284}$ The court determined that an "interrogation" of a juvenile offender by his probation officer had not occurred because the offender "volunteered [incriminating] information even after [he was] advised [] of his prerogative not to talk about [a pending murder] investigation." 285

\section{OPINIONS \& EXPERT OPINIONS: RULES 701 THROUGH 705}

\section{A. Rule 701: Opinion Testimony by Lay Witnesses}

In accordance with Rule 701, the opinion of a lay witness is confined "to one that is: (a) rationally based on the witness's perception; and (b) helpful to a clear understanding of the witness's testimony or to a determination of a fact in issue." ${ }^{286}$ Typically, that means the witness cannot base an opinion on information gathered from others, ${ }^{287}$ as an expert witness may. ${ }^{288}$ Nevertheless, there is a middle ground between a prototypical lay witness and an expert witness that broadens the scope of permissible testimony:

A witness not qualified to offer expert testimony under Evidence Rule 702 may be qualified as a "skilled witness" or "skilled lay observer." A skilled witness has a degree of knowledge that falls short of being declared an expert under Rule 702, but somewhat beyond that possessed by ordinary jurors. ${ }^{289}$

The Indiana Court of Appeals ruled that the opinions of two witnesses were properly admitted as those of skilled witnesses where the witnesses were each owners of businesses in the construction industry, each inspected the property at issue, each concluded that there were numerous defects in the property, and each "noted that the code violations found by the city inspector were consistent with

282. Johnson, 117 N.E.3d at 588.

283. Id. (citation and quotation marks omitted).

284. Id. (citation omitted).

285. Id.

286. IND. R. EvID. 701.

287. Tell City Boatworks, Inc. v. Ind. Dep't of State Revenue, 123 N.E.3d 732, 734 (Ind. T.C. 2019) ("[I]t appears that Ms. Little's opinions . . were based on information received from others not her own personal perceptions. Accordingly, Tell City has not shown that Ms. Little's testimony is admissible under Indiana Evidence Rule 701." (citation omitted)).

288. See InD. R. Evid. 703.

289. Clayton v. Smith, 113 N.E.3d 693, 702-03 (Ind. Ct. App. 2018), trans. denied, 123 N.E.3d 142 (Ind. 2019). 
their observations of the property." ${ }^{290}$ Those opinions were useful and admissible to determine whether the work done on the property added value. ${ }^{291}$

\section{B. Rule 702: Expert Witnesses}

"The trial court acts as the gatekeeper when determining the admissibility of opinion evidence under Indiana Evidence Rule 702."292 "Under this rule, a witness may be qualified as an expert by only one of the enumerated characteristics: knowledge, skill, experience, training, or education." ${ }^{293}$ The most highly anticipated expert-witness decision of the period was the Indiana Supreme Court's opinion in Tunstall v. Manning, ruling that "professional disciplinary history-limitations on professional licenses and the reasons underlying professional discipline - may be relevant to an expert's credibility." 294

Other important takeaways from the survey period include: a post-conviction action alleging ineffective assistance of counsel faces a challenge when based on failure to call an expert witness because " $[t]$ he trial court is not required to accept the opinion of experts", ${ }^{295}$ an expert on secondary education and employment is not a competent expert to opine "as to how a journalist should do his job"; 296 "expertise in training registrars and . . . help[ing] others learn" a healthcaremanagement system was sufficient expertise for witness to provide expert testimony on "training individuals in privacy and protected health information", ${ }^{297}$ expert testimony on the research tax credit is admissible due to the complexity of the provision in actions before the Indiana Tax Court, even though it ultimately concerns a matter of statutory interpretation; $;$ "298 and "[e]xpert testimony about 'battered woman's syndrome' is admissible at trial if it is relevant to a question at issue. ${ }^{299}$ Ironically, it is often easier to admit evidence on battered woman's syndrome if the expert has no knowledge of the individual victim, in which case "there [is little] chance the expert could be seen as vouching for the victim. $"{ }^{300}$

If the expert offers scientific opinion, then "the court [must be] satisfied that the scientific principles upon which the expert testimony rests are reliable, and

290. A House Mechs., Inc. v. Massey, 124 N.E.3d 1257, 1265-66 (Ind. Ct. App. 2019).

291. Id. at 1266 .

292. Clayton, 113 N.E.3d at 702.

293. Id.; see also IND. R. EvID. 702(a).

294. 124 N.E.3d 1193, 1198 (Ind. 2019).

295. Weisheit v. State, 109 N.E.3d 978, 988 (Ind. 2018), cert. denied, 139 S. Ct. 2749 (2019).

296. Pack v. Truth Publ'g Co., 122 N.E.3d 958, 968 (Ind. Ct. App. 2019).

297. Hayden v. Franciscan All., Inc., 131 N.E.3d 685, 695 n.5 (Ind. Ct. App. 2019), trans. denied, 141 N.E.3d 18 (Ind. 2020).

298. Tell City Boatworks, Inc. v. Ind. Dep’t of State Revenue, 123 N.E.3d 732, 735 (Ind. T.C. 2019).

299. Thevenot v. State, 121 N.E.3d 679, 686 (Ind. Ct. App. 2019).

300. Id. at 687. 
the court determines admissibility under 702(b)." 301 Indiana appellate courts affirmed admission of expert scientific testimony where a doctor engaged in a differential diagnosis before settling on a potential cause that could not be ruled out ${ }^{302}$ found that a challenge to a vocational economist's thoroughness of research in assessing a disability rating went to weight, not admissibility; ${ }^{303}$ and rejected "the propositions that only an economist can project future aggregate costs or that each individual cost must be reduced to present value for presentment to the jury," in an attempt to exclude the testimony of a life-care planner. ${ }^{304}$ Along the same line, it was reminded that Indiana has no "blanket rule [] prohibit[ing] non-physician healthcare providers from qualifying as expert witnesses as to medical causation under [Indiana] Evidence Rule 702."305

\section{Rule 703: Bases of Expert Opinion Testimony}

Rule 703 permits experts to base their opinions "on inadmissible evidence, provided that it is of the type reasonably relied upon by experts in the field." ${ }^{306}$ Although an expert may base an opinion on inadmissible evidence, the expert's opinion must ultimately be his or her own. ${ }^{307}$ For example, an expert may not be "merely 'a conduit' for placing 'physician's diagnoses into evidence without meaningful opportunities for cross-examination." 308

The Indiana Court of Appeals addressed a challenge to an expert's opinion as a mere conduit in Estate of Benefiel v. Wright Hardware Co ${ }^{309} \mathrm{~A}$ crucial issue in the case, which stemmed from a gas explosion, was the interpretation of an Indiana Code provision derived from the International Fuel Gas Code ("IFGC") mandating that leak testing should occur following "interruption of service," which is not a term defined in the Indiana Code. ${ }^{310}$ In order to ascertain the

301. Clayton v. Smith, 113 N.E.3d 693, 702 (Ind. Ct. App. 2018), trans. denied 123 N.E.3d 142 (Ind. 2019).

302. Golden Corral Corp. v. Lenart, 127 N.E.3d 1205, 1214 (Ind. Ct. App.), trans. denied, 138 N.E.3d 948 (Ind. 2019).

303. Clayton, 113 N.E.3d at 703.

304. Id. at 704-05

305. Sheng v. Bissonnette, No. 1:17-cv-03864-JRS-TAB, 2019 U.S. Dist. LEXIS 91299, at *5 (S.D. Ind. May 31, 2019) (quoting Totton v. Bukofchan, 80 N.E.3d 891, 894 (Ind. Ct. App. 2017)) (quotation marks omitted, alteration in original).

306. IND. R. EVID. 703.

307. Estate of Benefiel v. Wright Hardware Co., 128 N.E.3d 485, 491 (Ind. Ct. App. 2019) ("[A]lthough an expert may rely on others' opinions as a basis for his opinion if other experts in the field reasonably rely on such opinions, the expert must bring his own expertise to bear in reaching his opinion and may not simply repeat opinions of others or announce that other experts concur with his opinion with respect to the case.”), trans. denied, 141 N.E.3d 20 (Ind. 2020).

308. Id. at 490 (quoting Faulkner v. Markkay of Indiana, Inc., 663 N.E.2d 798, 801 (Ind. Ct. App. 1996)).

309. Id. at 490-92.

310. Id. at 487-88. 
meaning of the term, the expert sent an email to the body that authored the IFGC. ${ }^{311}$ At trial, the expert was permitted, over objection, to read the response to the jury. ${ }^{312}$ On appeal, the expert's testimony was challenged as being nothing more than a conduit for hearsay. ${ }^{313}$ The court of appeals agreed, finding the error sufficiently prejudicial to order a new trial:

Termed "the million dollar question," and battled over by experts on both sides, the jury was handed a definition of 'interruption of service' which was represented to be issued by the entity that also wrote the Code and purported to provide a definitive answer on an ultimate issue. During closing argument, counsel for [defendant] explained to the jury that because there was a disagreement on the definition, [the expert] contacted the [IFGC author] to "please help us to find what interruption of service is[.]" As such the jury was given the impression that this definition, interpreting the IFGC, was cloaked with authority to equally define the term in the Indiana Code. It was only after [the IFGC author's] opinion was read verbatim that [the expert] affirmed that his own opinion aligned with th[at] definition . . . . Viewed in the totality of the trial proceedings, [the] testimony in essence amounted to nothing more than a mere conduit to get otherwise inadmissible hearsay evidence in front of the jury. ${ }^{314}$

\section{Rule 704: Opinion on an Ultimate Issue}

"The common law did not allow an expert witness to inform the jury of his or her factual conclusion concerning the 'ultimate issue' in the case, because this was thought to invade the province of the jury. ${ }^{" 15}$ Federal courts abolished the ultimate-issue rule in 1972, by adopting Federal Rule of Evidence $704 .{ }^{316}$ In the same year, though still generally adhering to common-law evidentiary practice, Indiana followed suit. ${ }^{317}$ Although an opinion may "embrace[] an ultimate issue," "318 "[w]itnesses may not testify to opinions concerning intent, guilt, or innocence in a criminal case; the truth or falsity of allegations; whether a witness has testified truthfully; or legal conclusions." 319

Most often, Rule 704(b) is invoked to prohibit two types of testimony: legal conclusions and evidence regarding the accuracy of another witness's

311. Id. at 488 .

312. Id.

313. Id. at 489-91.

314. Id. at 492.

315. Nieves-Villanueva v. Soto-Rivera, 133 F.3d 92, 100 (1st Cir. 1997).

316. United States v. Rodriguez, 125 F. Supp. 3d 1216, 1257 (D.N.M. 2015).

317. DeVaney v. State, 288 N.E.2d 732, 737 (Ind. 1972); Southlake Limousine \& Coach, Inc. v. Brock, 578 N.E.2d 677, 684 (Ind. Ct. App. 1991).

318. IND. R. EVID. 704(a).

319. IND. R. EVID. 704(b). 
testimony-so-called "vouching" testimony. Nevertheless, the Indiana Supreme Court had opportunity to briefly discuss the reach of Rule 704(b) in excluding opinions concerning guilt, observing "that expert testimony regarding the cause of a fire (that does not tie the defendant to the fire) does not run afoul of Evidence Rule 704(b)." ${ }^{320}$ The other five published Indiana decisions from the survey period to address Rule 704(b) fell squarely into the categories of prohibiting legal conclusions and vouching.

In Kress v. State, the court of appeals briefly touched on the rationale of prohibiting vouching, noting that Rule 704(b) prohibits vouching "where a witness directly opines about 'the truth or falsity of allegations' or 'whether a witness has testified truthfully." "'321 The matter was addressed in greater depth through Watson v. State. ${ }^{322}$ The court of appeals explained the problem with vouching testimony as "result[ing] in an invasion of the province of the jurors in determining what weight they should place upon a witness's testimony." 323 In that light, the court found no problem with a witness being asked whether she had been honest when speaking with a forensic examiner and an attending nurse, responding in the affirmative, because the witness "was duly sworn to tell "the truth, the whole truth, and nothing but the truth." ${ }^{324}$ Having "agreed to provide truthful testimony and subsequently testif[ying] as to what she believed had happened to her[,]" the testimony "was simply [an] acknowledgement that she believed her own account of events." 325

The Indiana Tax Court also had occasions to apply Rule 704(b), focusing on whether an opinion was a legal conclusion. Although a "witness may [not] testify to . . . a legal conclusion, ${ }^{, 326}$ he or she may testify to standards of practice in a particular field, such as calling upon expertise in the maritime industry. ${ }^{327}$ Similarly, in Sahara Mart, Inc. v. Indiana Department of State Revenue, Judge Martha Wentworth found no problem with testimony that a business paid affiants "for services rendered as employees[,]" where the issue for the court was to determine whether certain persons were employees, since "whether an individual is an employee derives from the existence of certain facts, including whether one believes herself to be an employee." ${ }^{\text {"28 }}$

320. Weisheit v. State, 109 N.E.3d 978, 991 (Ind. 2018), cert. denied, 139 S. Ct. 2749 (2019).

321. 133 N.E.3d 742, 747 (Ind. Ct. App.), trans. denied, 138 N.E.3d 957 (Ind. 2019).

322. 134 N.E.3d 1038, 1045-46 (Ind. Ct. App. 2019), trans. denied, 141 N.E.3d 21 (Ind. 2020).

323. Id. at 1045 .

324. Id. at 1045-46.

325. Id. at 1046.

326. Tell City Boatworks, Inc. v. Ind. Dep't of State Revenue, 123 N.E.3d 732, 736 (Ind. T.C. 2019).

327. Tell City Boatworks, Inc. v. Ind. Dep't of State Revenue, 123 N.E.3d 728, 731 (Ind. T.C. 2019).

328. 114 N.E.3d 36, 47 (Ind. T.C. 2018). 


\section{HEARSAY: RULES 801 THROUGH 807}

\section{A. Rules 801 \& 802: Hearsay Generally Prohibited}

"Hearsay statements are not admissible, except pursuant to certain exceptions within the Rules of Evidence." ${ }^{229}$ But a statement is only excludable as hearsay if it "is a statement, other than one made by the declarant while testifying at trial, offered in evidence to prove the truth of the matter asserted." 330 That means the purpose for which a statement is offered is crucial to determining whether the statement is hearsay. ${ }^{331}$ For that reason, "statements providing context for other admissible statements are not hearsay," a rule which allowed text messages by one witness to be properly admitted to provide context for a criminal defendant's own incriminating messages. ${ }^{332}$

The focus on purpose for admission creates a possibility for abuse when a colorable argument exists to allow statements that the party wishes the jury to hear for the truth of the statements' contents. To safeguard against that danger, courts "require a reasonable level of assurance that such testimony [i]s neither offered by the proponent nor received by the trier of fact as evidence of the truth of the third party's statement." ${ }^{333}$ The primary question is: "Was the out-of-court statement used primarily to show the truth of its content, constituting inadmissible hearsay, or merely to explain subsequent police action, excluded from hearsay?" 334 Resolution of that question is found in a three-part test: "(1) does the testimony describe an out-of-court statement asserting a fact susceptible of being true or false; (2) what is the evidentiary purpose of the proffered statement; and (3) is the fact to be proved relevant to some issue in the case, and does any danger of prejudice outweigh its probative value." 335

A common avenue for introducing hearsay evidence that walks the line of impermissibility is "[c]ourse-of-investigation testimony[, which] is excluded from hearsay only for the limited purpose of bridging gaps in the trial testimony that would otherwise substantially confuse or mislead the jury." "336 "[T]he relevance of evidence of 'course of police work' testimony [i]s slight when the genesis of

329. S.K. v. Ind. Dep't of Child Servs. (In re Termination of the Parent-Child Relationship of S.K.), 124 N.E.3d 1225, 1231 (Ind. Ct. App.) (citing IND. R. EvID. 802), trans. denied, 134 N.E.3d 1025 (Ind. 2019).

330. Rivera v. State, 132 N.E.3d 5, 11 (Ind. Ct. App. 2019) (citing IND. R. Evid. 801(c)), trans. denied, 141 N.E.3d (Ind. 2020).

331. Hedrick v. State, 133 N.E.3d 179, 181 (Ind. Ct. App. 2019).

332. Cardosi v. State, 128 N.E.3d 1277, 1288 n.6 (Ind. 2019) (citation and quotation marks omitted).

333. Cook v. State, 119 N.E.3d 1092, 1096 (Ind. Ct. App.), trans. denied, 124 N.E.3d 59 (Ind. 2019).

334. Hedrick, 133 N.E.3d at 182 (citation and quotation marks omitted).

335. Id. (citation omitted).

336. Id. 
the investigation was not relevant to any contested issue in the case." ${ }^{937}$ Under that view, the prosecution lost appellate challenges to testimony by lawenforcement personnel in both Hedrick v. State ${ }^{338}$ and Cook v. State. ${ }^{339}$

There can be a more basic problem with excluding evidence as hearsay: It does not constitute a "statement" as defined by Rule $801(\mathrm{a}) .{ }^{340}$ That was an issue in Smith v. State, after an officer testified to whether persons he interacted with knew the defendant. ${ }^{341}$ The state argued that the testimony was not hearsay because the officer did not directly testify to the statements of others. ${ }^{342}$

While [the officer] did not repeat a declarant's statement, per se, he testified to information that could only have been obtained through statements made by the person or persons .... . Thus, those out of court statements were embedded in [the officer]'s testimony and were the predicate for that testimony, which was equivalent to repeating the declarant's out-of-court statements. ${ }^{343}$

Meaning "that the challenged testimony was hearsay, and the trial court abused its discretion when it overruled [] timely objections." 344

Even if a statement meets the definition of hearsay, it may still be excluded under Rule 801(d), which provides that certain statements otherwise meeting Rule 801(c)'s definition for hearsay are deemed to not be hearsay. ${ }^{345}$ A commonly relied upon definitional exception is Rule 801(d)(2)'s exclusion of statements by a party opponent. ${ }^{346}$ That exception may also extend to statements by coconspirators made "during and in furtherance of the conspiracy." 347 "To be admissible under this rule, the State must establish a conspiracy exists without using the statements at issue." ${ }^{348}$ The evidence to support the conspiracy may also be subject to exclusion by the rules of evidence, such as documentary evidence lacking sufficient authenticity. ${ }^{349}$

Moreover, Rule 801(d)(2) does not extend to statements made by a criminal defendant once taken into custody. ${ }^{350}$ For that reason, in Baker v. State, the

337. Id. at 182-83 (citation omitted).

338. Id. at 183 .

339. 119 N.E.3d 1092, 1096-97 (Ind. Ct. App.), trans. denied, 124 N.E.3d 59 (Ind. 2019).

340. IND. R. EVID. 801(a) (“'Statement' means a person's oral assertion, written assertion, or nonverbal conduct if the person intended it as an assertion.").

341. 114 N.E.3d 540, 543 (Ind. Ct. App. 2018).

342. Id.

343. Id.

344. Id.

345. IND. R. EvID. 801(d).

346. IND. R. EVID. 801(d)(2).

347. IND. R. Evid. 801(d)(2)(E).

348. Walters v. State, 120 N.E.3d 1145, 1154 (Ind. Ct. App. 2019).

349. Id.

350. Baker v. State, 111 N.E.3d 1046, 1050 (Ind. Ct. App. 2018) (citing Robinson v. State, 365

N.E.2d 1218, 1223 (Ind. 1977)), trans. denied, 123 N.E.3d 142 (Ind. 2019). 
Indiana Court of Appeals rejected application of Rule 801(d)(2) to statements made by the defendant in response to officer's questions because the defendant "had been apprehended, handcuffed, and ordered to sit on a curb, and was surrounded by several police officers when the unnamed officer asked [him] the question at issue." ${ }^{351}$ Baker was obviously in custody, so Rule 801(d)(2) does not apply.

Finally, it merits note that even if hearsay testimony is errantly presented, "[a] trial court's timely and accurate admonishment to the jury is presumed to cure any alleged error." ${ }^{352}$

\section{B. Rule 803: Statements for Medical Diagnoses, Business Records, and Learned Treatises ${ }^{353}$}

Rule 803, in conjunction with Rule 804, enumerates circumstances in which hearsay may still be admitted. ${ }^{354}$ The key distinction between Rules 803 and 804 is the latter's requirement that the declarant be unavailable. ${ }^{355}$ Rule 803 , to the contrary, applies irrespective of the availability of the declarant. ${ }^{356}$ The survey period contained published decisions addressing exceptions for excited utterances, ${ }^{357}$ statements made for medical diagnosis or treatment, ${ }^{358}$ recorded

351. Id. at 1050-51.

352. Hedrick v. State, 124 N.E.3d 1273, 1280, on reh'g, 133 N.E.3d 179 (Ind. Ct. App. 2019).

353. During the survey period, the Indiana Supreme Court approved a non-substantive amendment to Rule 803(3), effective immediately on January 22, 2019. Order Amending Ind. Rules of Evidence, No. 19S-MS-41, 2019 Ind. LEXIS 32 (Ind. Jan. 22, 2019). The amendment removed a scrivener's error that had created a redundancy in the official version of Rule 803 from a prior amendment. Order Amending Indiana Rules of Evidence, No. 94S00-1301-MS-30 (Ind. Sept. 13, 2013); see also Walters v. State, 120 N.E.3d 1145, 1154 n.9 (Ind. Ct. App. 2019) ("This amendment consisted of the removal of a clause from Indiana Evidence Rule 803(3) and does not affect our analysis herein.”). Even prior to the amendment, numerous sources simply omitted the redundant language. See, e.g., 13B Robert L. Miller, Jr., Indiana Practice: Courtroom HANDBook on Indiana Evidence 298 (2016-17 ed.). But see Castaneda v. State, No. 45A051601-CR-25, 2016 Ind. App. Unpub. LEXIS 1079, at *20 n.5 (Ind. Ct. App. Sep. 20, 2016) (unpublished) (recognizing redundancy by using ellipses to omit redundant text).

354. IND. R. EvID. 803; IND. R. Evid. 804.

355. Compare IND. R. EvID. 803, with IND. R. EvID. 804.

356. IND. R. EVID. 803.

357. IND. R. Evid. 803(2); see Chambless v. State, 119 N.E.3d 182, 188-90 (Ind. Ct. App.), trans. denied, 124 N.E.3d 50 (Ind. 2019); Ramsey v. State, 122 N.E.3d 1023, 1031-32 (Ind. Ct. App.), trans. denied, 129 N.E.3d 777 (Ind. 2019); Stinson v. State, 126 N.E.3d 915, 920-21 (Ind. Ct. App. 2019).

358. IND. R. EvID. 803(4); see Chambless, 119 N.E.3d at 190-92; Ramsey, 122 N.E.3d at 103031; S.K. v. Ind. Dep't of Child Servs. (In re Termination of the Parent-Child Relationship of S.K.), 124 N.E.3d 1225, 1231-32 (Ind. Ct. App.), trans. denied, 134 N.E.3d 1025 (Ind. 2019); Baxter v. State, 132 N.E.3d 1, 3-4 (Ind. Ct. App. 2019); Shoda v. Indiana, 132 N.E.3d 454, 465-70 (Ind. Ct. App. 2019). 
recollection, ${ }^{359}$ and records of regularly conducted activity. ${ }^{360}$

Subdivision (2) excepts excited utterances from exclusion. ${ }^{361}$

An excited utterance is a statement relating to a startling event or condition made while the declarant was under the stress of excitement that it caused. The rationale behind admitting excited utterances is that startling events and absence of opportunity for reflection vest the statements with reliability and reduce the likelihood of falsification. ${ }^{362}$

"To meet the excited utterance exception, three elements must be present: (1) a startling event or condition has occurred; (2) the declarant made a statement while under the stress or excitement caused by the event or condition; and (3) the statement was related to the event or condition." "The heart of the inquiry is whether the declarant was incapable of thoughtful reflection." ${ }^{\text {664 }}$ The statement may even be in response to a question, provided it arises under circumstances that it appears to be spontaneous and unrehearsed, "while still under the stress of excitement from the startling event." ${ }^{365}$

A key factor in determining admissibility is the amount of time that has passed between the exciting event and the utterance. ${ }^{366}$ Although " $[t]$ he event and utterance need not be contemporaneous, [ ] lapse of time is a factor to consider when deciding if the statement was spontaneous and unrehearsed[, and t]he longer the time between an event and an utterance, the greater the likelihood that the statement is a narrative of past events instead of an excited utterance." 367 Nevertheless, as the stress-causing event's degree of severity increases, so too does the likelihood a person was still operating under the stress or excitement hours after the fact. ${ }^{368}$

Chambless $v$. State found a 911 call by a victim of domestic battery admissible where the call was placed eighteen minutes after a fight in which the victim had been beaten and strangled, the victim had fled an apartment in cold

359. IND. R. EvID. 803(5); Pelissier v. State, 122 N.E.3d 983, 987-88 (Ind. Ct. App.), trans. denied, 130 N.E.3d 1146 (Ind. 2019).

360. IND. R. EviD. 803(6); Walters v. State, 120 N.E.3d 1145, 1153-56 (Ind. Ct. App. 2019); A.S. v. Ind. Dep't of Child Servs. (In re L.S.), 125 N.E.3d 628, 633-35 (Ind. Ct. App. 2019); J.C. v. Ind. Dep't of Child Servs., 134 N.E.3d 419, 428-29 (Ind. Ct. App. 2019); J.C. at 433-34 (Pyle, J., concurring); A.B. v. Ind. Dep't of Child Servs. (In re K.R.), 133 N.E.3d 754, 760-62 (Ind. Ct. App. 2019).

361. IND. R. EvID. 803(2).

362. Chambless, 119 N.E.3d at 189 (citations and quotation marks omitted).

363. Ramsey, 122 N.E.3d at 1032 (citation and quotation marks omitted).

364. Chambless, 119 N.E.3d at 189 (citation and quotation marks omitted).

365. Id. (citation and quotation marks omitted).

366. Id.

367. Id. (citations omitted).

368. Id. (citing Yamobi v. State, 672 N.E.2d 1344, 1346-48 (Ind. 1996) (statement made one hour after shooting admissible); Newbill v. State, 884 N.E.2d 383, 397 (Ind. Ct. App. 2008) (admitting rape victim's 911 call four hours after attack)). 
weather without time to wear a coat or winter boots, and the victim had trouble breathing, which further illustrated her distressed state of mind, was admissible. ${ }^{369}$ Those facts "establish that [the] statements during the 911 call were unrehearsed and made while still under the stress from the fight." ${ }^{, 370}$

The excited-utterance exception also came into use in Ramsey $v$. State to permit the statements of a woman who had been beaten over the course of several days and had been held captive via threat to the lives of her children, which were made during an interview with police, who were responding to a call after she escaped from the defendant. ${ }^{371}$ It was sufficient foundation for admission that the officer testified the victim "exhibited "behavior . . . of someone that ... had been through a traumatic ordeal and she was very upset and almost to [the] point of [being] inconsolable'; [she] was 'visibly shaken,' 'nervous,' and had '[e]xtremely severe' injuries . . . all over her body" and that the victim's contemporaneous medical records also "describe[d] her as 'very tearful,['] 'anxious,' 'frightened,' requiring 'emotional support,' 'tense,' [and] 'restless."'

In a third decision, the Indiana Court of Appeals again affirmed reliance on Rule 803(2). ${ }^{373}$ There, an evening of revelry turned sour when one of four persons celebrating the New Year brutally stabbed his friend while driving home. ${ }^{374}$ The driver, just half a mile from home, finished driving home then ran inside. ${ }^{375}$ Once inside, the driver told his awaiting girlfriend that "Cody . . . stabbed Mark." 376 Later, after driving the victim to a nearby mortuary, he called the girlfriend, stating that " $[\mathrm{t}] \mathrm{he}$ kid's dying . . . in your car," before hanging up and calling 911. ${ }^{377}$ At trial, the girlfriend testified to both statements, resulting in a hearsay challenge. ${ }^{378}$ The appellate court found "little doubt" that the friends, "who were celebrating New Year's Eve together, did not expect that, at the end of the evening, [defendant] would have stabbed his best friend." ${ }^{379}$ As a result, "[i]t was clearly a startling event" for the driver. ${ }^{380}$ The driver, upon realizing what had happened, exclaimed, "Are you fucking kidding me? That's your best friend." 381 When the driver arrived at the house, "he did not calmly get out of the car, instead, he jumped out, leaving the car running, with its lights on, and the car door open. ... [He] ordered [another friend] to go into the house and call 911.",382

369. 119 N.E.3d at $189-90$.

370. Id. at 190 .

371. 122 N.E.3d 1023, 1026 (Ind. Ct. App.), trans. denied, 129 N.E.3d 777 (Ind. 2019).

372. Id. at 1026 (ellipses and second and third alterations in original).

373. Stinson v. State, 126 N.E.3d 915, 920-22 (Ind. Ct. App. 2019).

374. Id. at 918 .

375. Id.

376. Id. at 920 (alterations and quotation marks omitted).

377. Id. at 920-21 (alteration in original, quotation marks omitted).

378. Id.

379. Id. at 921.

380. Id.

381. Id. (quotation marks omitted).

382. Id. (quotation marks omitted). 
Indeed, he even pushed the other friend "through the door because he "figured [defendant] might attack her [be]cause she was a witness." "'383 "Th[at] evidence strongly support[ed] a finding that the[] two statements were excited utterances." 384

Both Chambless and Ramsey also addressed a second hearsay exception: statements made for medical diagnosis or treatment. ${ }^{385}$ Embodied in Rule 803(4), the exception applies if "[a] statement []: (A) is made by a person seeking medical diagnosis or treatment; (B) is made for-and is reasonably pertinent to-medical diagnosis or treatment; and (C) describes medical history; past or present symptoms, pain or sensations; their inception; or their general cause." 386 It "is based upon the belief that a declarant's self-interest in seeking medical treatment renders it unlikely that the declarant would mislead the medical personnel person she wants to treat her." " 387 "[T] he declarant must subjectively believe that he or she was making the statement for the purpose of receiving medical diagnosis or treatment." ${ }^{388}$ Application turns on a two-prong inquiry: "First, is the declarant motivated to provide truthful information in order to promote diagnosis and treatment, and second, is the content of the statement such that an expert in the field would reasonably rely on it in rendering diagnosis or treatment." 389

In Ramsey, the court of appeals allowed narrative portions of medical records to be admitted, "in which [the victim] stated that [the defendant] prevented her from leaving [the] apartment by threatening to harm [her] children." 390 The choice to affirm admission stemmed from the severity and duration of the victim's injuries. ${ }^{391}$ The severity of injuries lent credibility to the statements because they made it more likely the victim "was motivated to provide truthful information to her medical providers in order to promote diagnoses and treatment." 392 And the duration of her captivity, accompanied by multiple days of beatings, meant that her "injuries were in different stages of severity and healing," making such information pertinent to the establishment of "an effective discharge plan and to prescribe an appropriate course of psychological counseling." ${ }^{393}$ Notably, the

383. Id. at $921 \mathrm{n} .4$.

384. Id. at 921 .

385. Chambless v. State, 119 N.E.3d 182, 190-92 (Ind. Ct. App.), trans. denied, 124 N.E.3d 50 (Ind. 2019); Ramsey v. State, 122 N.E.3d 1023, 1030-31 (Ind. Ct. App.), trans. denied, 129 N.E.3d 777 (Ind. 2019).

386. IND. R. EvID. 803(4).

387. Ramsey, 122 N.E.3d at 1030 (citation and quotation marks omitted).

388. Id. at 1031.

389. S.K. v. Ind. Dep't of Child Servs. (In re Termination of the Parent-Child Relationship of S.K.), 124 N.E.3d 1225, 1231 (Ind. Ct. App.) (citation and quotation marks omitted), trans. denied, 134 N.E.3d 1025 (Ind. 2019).

390. 122 N.E.3d 1023, 1030 (Ind. Ct. App.), trans. denied, 129 N.E.3d 777 (Ind. 2019).

391. Id. at 1031.

392. Id.

393. Id. 
court found important one of the concerns for providing future treatment was "the likelihood that she would renew her relationship with her abuser." ${ }^{\prime 394}$

With Rule 803(4), certain circumstances necessitating medical intervention have overlapped with the legal system with sufficient regularity to develop additional standards for application. One such circumstance is medical treatment of minors. That children often lack the full grasp of circumstances normally obvious to an adult opens the door to questioning whether a minor "subjectively believe[d] that he was making the statement for the purpose of receiving medical diagnosis or treatment. ${ }^{, 395}$ Outside the context of emergency treatment, an adult will typically understand that he or she has gone to a medical provider for the purpose of diagnosis or treatment. Young children, however, who must be brought by a guardian, "may not understand the nature of the examination, the function of the examiner, and may not necessarily make the necessary link between truthful responses and accurate medical treatment." ${ }^{396}$ To address that problem, "there must be evidence that the declarant understood the professional's role in order to trigger the motivation to provide truthful information." ${ }^{397}$ Under that standard, the Indiana Court of Appeals ruled it was error to permit a "therapist [to] testif[y] to her opinions concerning the children's mental state based on conversations she had . . . on the day [their f]ather killed their mother and statements made during therapy" because the conversations "were not for the purpose of therapy, but simply to help the children process their feelings and provide them with support." 398

Another tragically common area for reliance on Rule 803(4) is for victims of sexual assault. ${ }^{399}$ "Statements made by victims of sexual assault satisfy the second prong of the analysis because they assist medical providers in recommending potential treatment for sexually transmitted disease, pregnancy testing, psychological counseling, and discharge instructions." ${ }^{" 400}$ Such statements include the identity of the attacker. ${ }^{401}$

That is because:

[a]ll victims of domestic sexual abuse suffer emotional and psychological injuries, the exact nature and extent of which depend on the identity of the abuser. The physician generally must know who the abuser was in order to render proper treatment because the physician's treatment will necessarily differ when the abuser is a member of the victim's family or

394. Id.

395. S.K. v. Ind. Dep't of Child Servs. (In re Termination of the Parent-Child Relationship of S.K.), 124 N.E.3d 1225, 1231 (Ind. Ct. App.) (citation and quotation marks omitted), trans. denied, 134 N.E.3d 1025 (Ind. 2019).

396. Id. (quotation marks omitted).

397. Id. at 1231-32. (quotation marks omitted).

398. Id. at 1232 .

399. Baxter v. State, 132 N.E.3d 1, 3-4 (Ind. Ct. App. 2019).

400. Id. at 4 (citation and quotation marks omitted).

401. Id. at 3-4. 
household. ${ }^{402}$

As a result, the standard in Indiana allows a "domestic sexual abuser's identity ... under Rule 803(4) where the abuser has such an intimate relationship with the victim that the abuser's identity becomes 'reasonably pertinent' to the victim's proper treatment." ${ }^{403}$ Moreover, when the victim is a child, the identity of the perpetrator is "relevant and necessary in order for [the treatment provider] to know if [it can] discharge [the child] into" the custody of another "without [the child] being subjected to more abuse after" release. ${ }^{404}$ That additional standard led the Indiana Court of Appeals to affirm admission of statements identifying a young child's abuser in Baxter v. State. ${ }^{405}$

In Chambless, a medic responded to the victim's 911 call. ${ }^{406}$ While being treated, the victim stated that the defendant had assaulted her, slapped her in the face, strangled her with his hands, and that she escaped "just in time." ${ }^{407}$ Although "statements that identify the perpetrator ... [are] usually not necessary to provide effective medical care," they may still be within the ambit of the exception "where the identity of the perpetrator is relevant to appropriate diagnosis and treatment." $" 408$ The court analogized the reasoning applied in child-abuse cases, wherein "knowledge of the perpetrator is important to the treatment of psychological injuries that may relate to the identity of the perpetrator and to the removal of the child from the abuser's custody or control," and found the same reasoning appropriate to the victim's statements because the defendant was her live-in boyfriend. ${ }^{409}$ Finding the standard for domestic sexual abuse met, the court of appeals affirmed admission of the statements. ${ }^{410}$

The sexual-abuse standard as applied to a child was the key to admitting evidence of a six-year-old child's statements to a nurse and a therapist in Shoda v. State. ${ }^{411}$ As to the nurse, who the child saw shortly after revealing the molestation, the Indiana Court of Appeals affirmed admission because the nurse recorded her usual practices in her report, her practice was to explain the role of the nurse and examination to the child, "[she] discussed why nurses need to know what happened for purposes of medical treatment," and her report indicated the child understood her "role as a nurse and the purpose of the examination and treatment." ${ }^{" 12}$ With regard to the therapist, who the child saw on a later occasion,

402. Id. at 4 (citation and quotation marks omitted).

403. Id. (citation and quotation marks omitted).

404. Id.

405. Id. at 2,4 .

406. 119 N.E.3d 182, 186 (Ind. Ct. App.), trans. denied, 124 N.E.3d 50 (Ind. 2019).

407. Id.

408. Id. at 190-91 (citations omitted).

409. Id. at 191 (citations and quotation marks omitted).

410. Id. The court noted that the statements to the medic may also have been admissible as excited utterances. $I d$. at $191 \mathrm{n} .5$.

411. 132 N.E.3d 454, 465-70 (Ind. Ct. App. 2019).

412. Id. at 468 . 
the therapist explained to the child why they were meeting, "the purpose of "what we do[,]' and explained mental health to her." ${ }^{\text {413 }}$ Since the child "appeared to understand the therapeutic purpose behind [the] interaction," showing that she understood her statements were for obtaining treatment, the statements fit within the scope of Rule 803(4) and were properly admitted. ${ }^{414}$

Pelissier $v$. State concerned the recorded-recollection exception of Rule 803(5). ${ }^{415}$ That exception applies if the record: "(A) is on a matter the witness once knew about but now cannot recall well enough to testify fully and accurately; (B) was made or adopted by the witness when the matter was fresh in the witness's memory; and (C) accurately reflects the witness's knowledge."'416 Part of the foundation for admission is "acknowledgment that the statement was accurate when it was made," meaning the statement should be excluded "when the witness cannot vouch for the accuracy of the statement nor remember having made the statement."417

At trial, the witness testified "he could not remember the events of the night of the shooting or any details of the subsequent [recorded] statements he made to police." ${ }^{\prime 18}$ On appeal, the court briefly looked to Rule 803(5) but never reached a conclusion on application of the exception, instead finding any error harmless. ${ }^{419}$ Nevertheless, some guidance can be found for future application by looking to what relevant factors the court considered when analyzing the exception. The court found it notable that the recollection-i.e. the statements made to police - were recorded on video, not merely written. ${ }^{420}$ Moreover, it was of import that the witness "never indicated what he said was not true, and 'repeatedly stated that he had already answered the questions and referred the questioner to the video[.]" "421 Lastly, the video showed the witness "indicated he was telling the truth" at the time of giving the recorded statement. ${ }^{422}$ It is entirely possible that those factors, standing alone, would be enough to satisfy Rule 803(5), but Pelissier does not mandate that result.

Also garnering numerous analyses during the survey period was Rule 803(6)'s exception for records of regularly conducted activity. The exception requires a five-part showing:

(A) the record was made at or near the time by-or from information transmitted by - someone with knowledge;

(B) the record was kept in the course of a regularly conducted activity of a business, organization, occupation, or calling, whether or not for

\footnotetext{
413. Id. at 469 .

414. Id. at $469-70$.

415. 122 N.E.3d 983, 987-88 (Ind. Ct. App.), trans. denied, 130 N.E.3d 1146 (Ind. 2019).

416. IND. R. Evid. 803(5).

417. Pelissier, 122 N.E.3d at 987 (citation and quotation marks omitted).

418. Id.

419. Id. at 988 .

420. Id.

421. Id. (alteration in original).

422. Id.
} 
profit;

(C) making the record was a regular practice of that activity;

(D) all these conditions are shown by the testimony of the custodian or another qualified witness, or by a certification that complies with Rule 902(11) or (12) [the rule on self-authentication] or with a statute permitting certification; and

(E) neither the source of the information nor the method or circumstances of preparation indicated a lack of trustworthiness. ${ }^{423}$

"This hearsay exception is grounded on the theory that records of regularly conducted activity are reliable because they can be checked systematically." Put another way, it "is based on the fact that the circumstances of preparation assure the accuracy and reliability of the entries. ${ }^{\circ 25}$

Three cases considered whether the exception applied to parental drug-test results in actions seeking to terminate parental rights. The first of the decisions was In re L.S., which ruled exhibits containing a mother's drug-test results were not within the reach of the exception because:

Although the [accompanying] affidavits state that the laboratory reports were maintained in the normal course of business activity as business records, what [the court] consider[s] is whether a business depends on those records to function. [The lab] does not depend on these records to operate or to conduct business. Rather, the drug test results were documented for the benefit of DCS. Therefore, [the] exhibits were inadmissible as hearsay and should not have been admitted. ${ }^{426}$

The second case, J.C. v. Indiana Department of Child Services, echoed L.S. ${ }^{427}$ But the J.C. panel did not decide whether admission was error, instead skipping to the conclusion that even if there was error, it was harmless, ${ }^{428}$ which had also been the conclusion of $L . S^{429}$

While J.C. did not depart from L.S., In re K.R.-from the same panel as J.C.- - rejected L.S. ${ }^{430}$ The K.R. panel found analogous a substantial number of cases allowing blood-alcohol results as well as blood and DNA results under Rule 803(6). ${ }^{431}$ Rejecting the conclusion of L.S., K.R. held that drug-test results such

423. IND. R. EvID. 803(6).

424. A.B. v. Ind. Dep't of Child Servs. (In re K.R.), 133 N.E.3d 754, 760 (Ind. Ct. App. 2019) (citation omitted).

425. Id. (citation and quotation marks omitted).

426. A.S. v. Ind. Dep't of Child Servs. (In re L.S.), 125 N.E.3d 628, 633-34 (Ind. Ct. App. 2019).

427. 134 N.E.3d 419, 422 (Ind. Ct. App. 2019).

428. Id.

429. In re L.S., 125 N.E.3d at 635-36.

430. A.B. v. Ind. Dep't of Child Servs. (In re K.R.), 133 N.E.3d 754, 760-62 (Ind. Ct. App. 2019).

431. Id. at 761 . 
as those in L.S., J.C., and K.R. are admissible, relying in part on decisions from other states. ${ }^{432}$ With transfer having been obtained in K.R., the next survey will address the Indiana Supreme Court's resolution of this split in precedent. ${ }^{433}$

The business-records exception was also at issue in the context of phone records in Walters v. State. ${ }^{434}$ The problem, there, was "the certificate offered to authenticate the phone records . . . was issued approximately eighteen months after the records were obtained, $\mathrm{d}[\mathrm{id}]$ not contain the phone number for which the search warrant requested records, ... . the number of pages it purports to authenticate, and ... the dates the records encompass. ${ }^{.435}$ Absent testimony of the custodian or another qualified witness, the only avenue for admission was through the certificate. ${ }^{436}$

Even if an affidavit purports to authenticate a business document, that evidence still may be excluded if "the circumstances of the record's preparation indicate a lack of trustworthiness." . . . By its tardiness and lack of conformity with the other [phone] certification used in this trial, this certificate lacks indicia of reliability. This certificate contains no other identifying characteristics, aside from [the phone company]'s internal case number. Without a timeframe reference and identification of the records in some way separate from the [phone company's] case number, it is unclear what documents this certificate purports to certify. ${ }^{437}$

Accordingly, admission of the phone records was error. ${ }^{438}$

\section{Rule 804: Hearsay Exceptions for Unavailable Declarants}

As with Rule 803, the exceptions under Rule 804, which permits hearsay testimony only where the declarant is unavailable, are varied and delineated in the rule. ${ }^{439}$ Two of the exceptions - former testimony at trial ${ }^{440}$ and statements against interest $\mathrm{t}^{44}$ - drew attention during the survey.

In McWhorter v. State, the court of appeals affirmed admission of testimony from a witness who was unavailable for the second trial after having testified at

432. Id. at 762 (citing In re S.D.J., 664 S.E.2d 818, 822 (N.C. Ct. App. 2008); J.G. v. State, 685 So.2d 1385, 1385 (Fla. Ct. App. 1997); Montoya v. Texas, 832 S.W.2d 138, 141 (Tex. App. 1992); Pennsylvania v. Kravontka, 558 A.2d 865, 871 (Pa. Super. Ct. 1989)).

433. In re K.R., 154 N.E.3d 818 (Ind. 2020) (affirming admission of the results).

434. 120 N.E.3d 1145, 1154-56 (Ind. Ct. App. 2019).

435. Id. at 1155 .

436. Id.

437. Id. (citations omitted).

438. Id. 1155-56.

439. IND. R. EVID. 804(b).

440. IND. R. EVID. 804(b)(1).

441. IND. R. EvID. 804(b)(3). 
the first. ${ }^{442}$ The primary challenge was the defendant's claim "that he lacked a similar motive to develop [the] testimony during the first trial because his defense was one of accident and he did not interject the issue of sudden heat." ${ }^{\prime 43}$ One of the two requirements for invoking Rule 804(b)(1)'s exception for former testimony is that it " is now offered against a party who had . . an opportunity and similar motive to develop it by direct, cross-, or redirect examination." ${ }^{444}$ But "[t]he plain language of Rule 804(b)(1) requires only that the opponent have had a 'similar' motive to develop the former testimony." ${ }^{445}$ Despite the change in focus, at the first trial, the declarant "was the sole eyewitness testifying[, and the defendant] was highly incentivized to highlight any problem with her perception and recollection and to elicit from her any evidence that tended to negate or lessen his criminal culpability." ${ }^{\$ 46}$

The statement-against-interest exception arose in the odd posture of review from a probation-revocation determination in Votra v. State ${ }^{447}$ The posture is odd because "the rules of evidence do not strictly apply in probation revocation proceedings." ${ }^{\prime 48}$ Nevertheless, the Indiana Court of Appeals used the structure of Rule 804(b)(3) to guide its analysis. ${ }^{449}$ The court began by recognizing that "corroborating evidence is not strictly required by [] Rule 804(b)(3), [but] such corroboration can support a trial court's determination that the hearsay testimony was reliable." ${ }^{" 450}$ In that instance, there was sufficient corroborative evidence and experience with the underlying facts that the trial court was within its discretion to admit the statements from the defendant's girlfriend. ${ }^{451}$ The court did, however, instruct that "the better practice might have been to present live testimony in support of the documentary evidence." 452

\section{Rule 805: Hearsay Within Hearsay}

Merely satisfying an exception to hearsay is not always enough. "If a statement involves hearsay within hearsay, also known as multiple hearsay or double hearsay, the statement may [] be admitted if each layer of hearsay qualifies under an exception to the hearsay rule." ${ }^{453}$ But, such "statements are not

442. McWhorter v. State, 117 N.E.3d 614, 618 (Ind. Ct. App. 2018), trans. denied, 129 N.E.3d 783 (Ind. 2019), cert. denied, 140 S. Ct. 941 (2020).

443. Id.

444. Id.

445. Id.

446. Id.

447. 121 N.E.3d 1108, 1115-16 (Ind. Ct. App. 2019).

448. Id. at 1115 .

449. Id.

450. Id. (quotation marks and citation omitted).

451. Id. at 1116 .

452. $I d$.

453. Minor v. State, 36 N.E.3d 1065, 1070 (Ind. Ct. App. 2015) (citation and quotation marks omitted; second alteration in original); see also IND. R. EVID. 805. 
admissible unless each layer of hearsay qualifies under an exception to the hearsay rule." ${ }^{\prime 54}$ In Cook v. State, once the court determined out-of-court statements made to a detective were hearsay, the additional problem arose of multiple hearsay. ${ }^{455}$ The proffered testimony was the quintessential daisy chain of one person making a statement to another person, the second person relaying that statement to a third, and then the third person to the detective. ${ }^{456}$ Because the defendant did not establish an exception for each layer of hearsay, the trial court properly excluded the evidence. ${ }^{457}$

VIII. AUTHENTICATION \& IDENTIFICATION: RULES 901 THROUGH 903

\section{A. Rule 901: Authenticating Evidence}

To be admissible, the proponent of evidence must authenticate it by "produc[ing] evidence sufficient to support a finding that the item is what the proponent claims it is." 458

Absolute proof of authenticity is not required. The proponent of the evidence needs to establish only a reasonable probability that the document is what it is claimed to be. Once this reasonable probability is shown, any inconclusiveness regarding the exhibit's connection with the events at issue goes to the exhibit's weight, not its admissibility. Additionally, authentication of an exhibit can be established by either direct or circumstantial evidence. ${ }^{459}$

The past two surveys revealed courts struggling to apply authentication requirements to modern technology. ${ }^{460}$ This survey period was no different.

In Rogers $v$. State, it was a matter of authenticating authorship of text messages. ${ }^{461}$ "Rule 901(b)(1) provides that "evidence that satisfies the requirement' includes '[t]estimony that an item is what it is claimed to be, by a witness with knowledge."'462 Authenticity was adequately established by the witness testifying she knew the defendant, that the exhibit containing the text

454. Cook v. State, 119 N.E.3d 1092, 1097 (Ind. Ct. App.), trans. denied, 124 N.E.3d 59 (Ind. 2019).

455. $I d$.

456. Id. at 1096.

457. Id. at 1097 .

458. IND. R. EVID. 901(a).

459. Rogers v. State, 130 N.E.3d 626, 629-30 (Ind. Ct. App. 2019) (citation and quotation marks omitted); accord Walters v. State, 120 N.E.3d 1145, 1154 (Ind. Ct. App. 2019) ("Without being required to provide absolute proof of authenticity, the proponent must present '[e]vidence that establishes a reasonable probability that the document is what it is claimed to be." (citation omitted, alterations in original)).

460. 2017 Survey, supra note 85, at 1077-79; 2018 Survey, supra note 279 , at 748-50.

461. Rogers, 130 N.E.3d at 629-30.

462. Id. at 630 (quoting IND. R. EvID. 901(b)(1)) (alteration in original). 
messages "accurately reflected the text messages she received," that the defendant was the only person saved in her phone as "Randy," "and that if she were receiving text messages from Randy it would be from the defendant." ${ }^{\text {"463 }}$ Moreover, the content of the messages referred to the relationship between the witness and defendant, mentioned the first name matching a person with whom the defendant resides, "mentioned the night of the offense, included an apology, informed [the witness] that she did not have to testify, and referenced the prospect of jail time." ${ }^{\$ 64}$ In light of that detail, the appellate court found no abuse of discretion allowing use of the text messages. ${ }^{465}$

The court of appeals also advised: "Although this particular text message was adequately authenticated by the witness's testimony, the better practice would be to ask further detailed questions i.e., whether the message appears to have been altered in any way." ${ }^{\circ 66}$

\section{B. Rule 902(11): Self-Authentication of Certified Domestic Records}

Bypassing the authentication procedures of Rule 901, Rule 902 designates twelve types of evidence that are self-authenticating. ${ }^{467}$ Walters $v$. State addressed one of the categories in assessing whether phone records were sufficiently authenticated. ${ }^{468}$ The state attempted to show authentication through Rule 902(11), which deems business records admissible through Rule 803(6) as selfauthenticating when "they are accompanied by 'a certification under oath of the custodian." 469 The Indiana Court of Appeals, however, rejected that basis, finding:

the certificate offered to authenticate the phone records . . . was issued approximately eighteen months after the records were obtained, does not contain the phone number for which the search warrant requested records, does not contain the number of pages it purports to authenticate, and does not contain the dates the records encompass. ${ }^{470}$

An affidavit certifying the authenticity of business documents "may be excluded if 'the circumstances of the record's preparation indicate a lack of

463. Id.

464. Id.

465. Id. The key argument to the contrary by the defendant was "that the information in the text messages that things 'got out of control that night' could have come from anyone cursorily familiar with him and the events that transpired on the night the incident took place" and that the messages referred to knowing each other for fifteen years despite the witness testifying at trial that they "had known each other for ten to eleven years." Id. at 629.

466. Id. at $630 \mathrm{n} .1$.

467. IND. R. EvID. 902.

468. 120 N.E.3d 1145, 1154-56 (Ind. Ct. App. 2019).

469. Id. at 1154-55 (quoting IND. R. EVID. 902(11)) (alteration in original).

470. Id. at 1155 . 
trustworthiness."' ${ }^{471}$ As to these deficiencies, the court instructed:

Although a valid certificate of authenticity may not need everything [defendant] complains this certificate is lacking, it does require some level of trustworthiness. By its tardiness and lack of conformity with the other [phone company] certification used in this trial, this certificate lacks indicia of reliability. This certificate contains no other identifying characteristics, aside from [the company]'s internal case number. Without a timeframe reference and identification of the records in some way separate from the [company's] case number, it is unclear what documents this certificate purports to certify. ${ }^{472}$

With authentication lacking, the trial court abused its discretion in admitting the phone records. ${ }^{473}$

\section{CONTENTS OF WRITINGS \& RECORDINGS: RULES 1001 THROUGH 1008}

Drawing its name from the 1700 decision Ford v. Hopkins, ${ }^{474}$ the so-called "best evidence rule" has long been a misnomer for what is more accurately referred to as the "original document rule." ${ }^{.475}$ What remained of the common-law rule, after nearly three centuries of refinement, was "formalized through the modern Rules of Evidence employed by both state and federal courts," stretching from Rule 1001 to Rule $1008 .^{476}$ Several of the rules embodying the originaldocument rule were examined by the Indiana Court of Appeals in Zartman $v$. Zartman. ${ }^{477}$

Former Chief Justice, now-Senior Judge Randall Shepard authored the unanimous opinion of the appellate panel, necessitating a trek through caselaw and treatises to suss out the intricacies of the rule. ${ }^{478}$ The controversy followed the generational transfer of properties from parents to children by way of revocable

471. Id. at 1155 (quoting Speybroeck v. State, 875 N.E.2d 813, 819 (Ind. Ct. App. 2007)).

472. Id. at 1155 (citation omitted).

473. Id. at 1156 .

474. 1 Salk. 283, 91 Eng. Rep. 250 (1700); see also CLEARY, supra note 250, at $§ 229$ (attributing origin of name to Ford v. Hopkins); Dale A. Nance, The Best Evidence Principle, 73 IOWA L. REv. 227, 234 n.33 (1988) (same).

475. Guillermety v. Sec'y of Educ. of the United States \& Sec'y of Treasury of the United States, 341 F. Supp. 2d 682, 689 n.5 (E.D. Mich. 2003); J. AlexANDER TANFord \& Richard M. Quinlan, Indiana Trial Evidence Manual $\S 5.1(2 \mathrm{~d}$ ed. 1987) ("There is no such thing as a general 'best evidence rule' . . . There is a rule requiring a party to either produce or account for the original document . . . " (emphasis in original); CLEARY, supra note 250, at $\S 229$ ("The only actual rule that the 'best evidence' phrase denotes today is the rule requiring the production of the original writing.").

476. Zartman v. Zartman, 127 N.E.3d 242, 243 (Ind. Ct. App.), trans. denied, 134 N.E.3d 1026 (Ind. 2019).

477. Id.

478. Id. at 244 . 
trusts. ${ }^{479}$ Key to the resolution of the dispute amongst siblings was the documents forming the mother's trust. ${ }^{480}$ "Because the parties have only the first and last pages of [the] original trust document, they turned to the series of rules about 'best evidence' to prove the content of the trust and the amendment."

Indiana Evidence Rule 1002 provides that an original writing is required in order to prove its content unless the rules of evidence or a statute provide otherwise. In the absence of an original, Rule 1004 states that other evidence of the content of a writing is admissible if all originals are lost or destroyed, and the loss or destruction was not caused by the proponent acting in bad faith. Evidence Rule 1007 allows proof of the content of a writing by the testimony, deposition, or written statement of the party against whom the evidence is offered. Finally, Rule 1008 provides:

Ordinarily, the court determines whether the proponent has fulfilled the factual conditions for admitting other evidence of the content of a writing, recording, or photograph under Rule 1004 or 1005 . But in a jury trial, the jury determines in accordance with Rule 104(b) any issue about whether:

(a) an asserted writing, recording, or photograph ever existed;

(b) another one produced at the trial or hearing is the original; or

(c) other evidence of content accurately reflects the content. ${ }^{482}$

There was no dispute that Rule 1004 was satisfied as the original trust documents were unavailable, lost, or destroyed. ${ }^{483}$ Accordingly, two of the siblings sought to establish the content of the trust by way of summary judgment. ${ }^{484}$ The undisputed evidence submitted at summary judgment indicated that the mother's trust documents had not been seen in full since 2009, that the father's trust documents were still existent and submitted in support of the motion, and that the mother's trust was identical to the trust of the father "with the exception of the substitution of names, gender pronouns, and the like where appropriate. $" 485$

Summary judgment was denied, however, because the trial judge interpreted Rule 1008 as necessitating that the jury, not the court, determine the content of the missing writing. ${ }^{486}$ The court of appeals disagreed, recognizing that "it would

479. Id.

480. Id.

481. Id. at 245 .

482. Id.

483. Id.

484. $I d$.

485. Id.

486. Id. at 246 ("Based upon what the parties have reported to the Court, it appears that the requirements of IRE 1004(a) and (b) are satisfied with respect to the documents associated with the 
be illogical to read Rule 1008 as requiring a trial judge to disregard completely the undisputed designated evidence as to the content of a lost writing" and that "the more pragmatic reading of the rule is that it requires evidentiary disputes about the content of a lost writing be determined by a jury only during a jury trial." ${ }^{487}$ Accompanying pragmatism was a decision interpreting the identical Federal Rule of Evidence 1008 entrusting the decision to the trier of fact, which is the court at summary judgment. ${ }^{488}$ Finding no genuine dispute of material fact in the content of the mother's trust documents, the court of appeals held that summary judgment should have been granted and ordered the case reversed and remanded. ${ }^{489}$

\section{COMMON LAW RULES: CORPUS DELICTI, RES IPSA LOQUITUR, PAROL EVIDENCE \& SPOLIATION}

Although the Indiana Rules of Evidence largely supplanted common-law evidentiary practice, "[i]f the[] rules do not cover a specific evidence issue, common or statutory law shall apply." 490 Numerous common-law evidentiary issues were addressed during the survey period.

\section{A. Corpus Delicti Rule}

A confession to guilt made outside the confines of a court, standing alone, is an insufficient basis for a criminal conviction in Indiana. ${ }^{491}$ Embodied in the corpus delicti rule, the rationale for exclusion "is to prevent . . . confession to a crime which never occurred." ${ }^{492}$ That is not to say confessions are inadmissible. Instead, "admission . . . requires some independent evidence of commission of the crime charged. The independent evidence need not prove that a crime was committed beyond a reasonable doubt, but merely provide an inference that the crime charged was committed." ${ }^{~} 933$ Circumstantial evidence of guilt is sufficient to make a confession admissible. ${ }^{494}$

establishment and/or operation of the Marilyn M. Zartman Revocable Trust. The Plaintiffs may seek to prove the content of such writings through the application of IRE 1007. However, IRE 1008(c) provides that the jury is to determine in accordance with IRE 104(b) any issue about whether evidence of the content of such writings accurately reflects the content." (emphasis in original)).

487. Id. (emphasis in original).

488. Id. at 247 (citing Coltec Indus. v. Zurich Ins. Co., No. 99 C 1087, 2002 U.S. Dist. LEXIS 18979 (N.D. Ill. Sept. 30, 2002)).

489. Id.

490. IND. EvID. R. 101(b).

491. Roach v. State, 119 N.E.3d 170, 172 (Ind. Ct. App.), trans. denied, 127 N.E.3d 222 (Ind. 2019); Gibson v. State, 111 N.E.3d 247, 253 (Ind. Ct. App. 2018), trans. denied, 120 N.E.3d 559 (Ind. 2019).

492. Gibson, 111 N.E.3d at 253 (citation and formatting omitted).

493. Id. (citation and formatting omitted); see also Roach, 119 N.E.3d at 172.

494. Gibson, 111 N.E.3d at 253; Roach, 119 N.E.3d at 172. 
In two reported decisions, the Indiana Court of Appeals denied challenges to convictions based upon admission of confessions. ${ }^{495}$ Gibson v. State stemmed from a conspiracy to commit robbery. ${ }^{496}$ The defendant argued that his inculpatory statements presented the sole evidence to establish the conspiracy. ${ }^{497}$ The argument was unsuccessful because a witness testified she saw the defendant commit the robbery with another person, and such evidence of working together to commit a robbery was sufficient "circumstantial evidence to support a reasonable inference that they had made a plan before they arrived to commit the robbery." 498

In Roach v. State, the defendant was convicted for abuse of a corpse and for criminal confinement. ${ }^{499}$ On appeal, the defendant contested only his conviction for abuse of a corpse. ${ }^{500}$ "[W] here a defendant confesses to several crimes of varying severity within a single episode, strict and separate application of the corpus delicti rule to each offense adds little to the ultimate reliability of the confession once independent evidence of the principal crime is introduced." ${ }^{01}$ So long as there is "independent evidence of the principal offense," the confession alone may suffice to convict "the other crimes in the same episode." ${ }^{02}$ The presence of the defendant's DNA “on duct tape and on a cigarette butt collected from the abandoned attic room where [the victim]'s mummified body was discovered" was sufficient independent evidence to permit presentation of the confession to the jury and to sustain the verdict. ${ }^{503}$

\section{B. Res Ipsa Loquitur}

Often overlooked when considering evidentiary procedures is the doctrine of res ipsa loquitor. "Res ipsa loquitur literally means 'the thing speaks for itself." " 504 It "is a rule of evidence that permits an assumption that in some situations an occurrence is so unusual that, absent a reasonable justification or explanation, the person in control of the situation should be held responsible." ${ }^{, 505}$ "The doctrine operates on the premise that negligence, like any other fact or

495. Gibson, 111 N.E.3d at 253-54; Roach, 119 N.E.3d at 172-73.

496. 111 N.E.3d at 253-54.

497. Id. at 254 .

498. Id.

499. 119 N.E.3d at 171.

500. Id. at 172 .

501. Id. (citation and formatting omitted).

502. $I d$.

503. Id. at 172-73.

504. Till v. Dolgencorp, LLC, No. 1:18-cv-00127-TWP-DLP, 2019 U.S. Dist. LEXIS 117715, at *10 (S.D. Ind. July 16, 2019) (quoting Gold v. Ishak, 720 N.E.2d 1175, 1180 (Ind. Ct. App. 1999)) (further quotation marks omitted), aff'd, 801 F. App'x 428 (7th Cir. 2020).

505. Golden Corral Corp. v. Lenart, 127 N.E.3d 1205, 1218-19 (Ind. Ct. App.) (citation and quotation marks omitted), trans. denied, 138 N.E.3d 948 (Ind. 2019). 
condition, may be proved by circumstantial evidence."506 "Nevertheless, the doctrine of res ipsa loquitur is a limited exception to the general rule that the mere fact of injury will not create an inference of negligence." ${ }^{907}$ In order to invoke the doctrine, a plaintiff must satisfy a two-part test showing: "1) the injuring instrumentality is . . . under the management or exclusive control of the defendant or his servants, and 2) the accident is such as in the ordinary course of things does not happen if those who have management of the injuring instrumentality use proper care."

One of the most common contexts for invoking the doctrine is in pursuing claims for medical malpractice. ${ }^{509}$ The reason for its use in that setting is because "[u]nless satisfied by the rule of res ipsa loquitur, a medical malpractice plaintiff is ordinarily required to present expert opinion that a defendant health care provider's conduct fell below the applicable standard of care." ${ }^{510}$ As a result, whenever possible, plaintiffs in such actions seek to alleviate the need for expert testimony and have a finding under the doctrine. That does not mean, however, the doctrine is easily applied to medical malpractice claims. "In the medical malpractice context, application of this exception is limited to situations in which the defendant's conduct is so obviously substandard that a jury need not possess medical expertise in order to recognize the defendant's breach of the applicable standard of care." 511 "Cases that do not require expert testimony generally involve the physician's failure to remove surgical implements or foreign objects from the patient's body," 512 such as leaving mesh in a patient's abdomen, ${ }^{513}$ a "patient's oxygen mask catching fire during surgery," $" 14$ or a "wire left in [a patient's] breast following biopsy." 515 Two cases from the survey period exemplify the difficulty of invoking the doctrine in that setting.

In St. Mary's Ohio Valley Heart Care, LLC v. Smith, the court of appeals found the doctrine inappropriate to assess the decision to perform a lobectomy

506. Bell v. Wal-Mart Stores E. LP, No. 3:17-cv-705 JD, 2019 U.S. Dist. LEXIS 41382, at *5 (N.D. Ind. Mar. 14, 2019) (quoting Rector v. Oliver, 809 N.E.2d 887, 889 (Ind. Ct. App. 2004)) (quotation marks omitted).

507. St. Mary's Ohio Valley Heart Care, LLC v. Smith, 112 N.E.3d 1144, 1150 (Ind. Ct. App. 2018), trans. denied, 121 N.E.3d 127 (Ind. 2019).

508. Golden Corral, 127 N.E.3d at 1219 (internal citation and formatting omitted).

509. See e.g., St. Mary's, 112 N.E.3d at 1150-51; Gearnhardt v. United States, No. 2:17-cv00186-JRS-DLP, 2018 U.S. Dist. LEXIS 192822, at*17-18 (S.D. Ind. Nov. 13, 2018).

510. Overshiner v. Hendricks Reg'1 Health, 119 N.E.3d 1124, 1132 (Ind. Ct. App.), trans. denied, 132 N.E.3d 379 (Ind. 2019).

511. St. Mary's, 112 N.E.3d at 1150 (citation and quotation marks omitted).

512. Gearnhardt, 2018 U.S. Dist. LEXIS 192822, at*17 (quoting Simms v. Schweikher, 651 N.E.2d 348, 350 (Ind. Ct. App. 1995)).

513. Id. (citing Ciesiolka v. Selby, 261 N.E.2d 95 (Ind. Ct. App. 1970)).

514. Till v. Dolgencorp, LLC, No. 1:18-cv-00127-TWP-DLP, 2019 U.S. Dist. LEXIS 117715, at *13 (S.D. Ind. July 16, 2019) (citing Cleary v. Manning, 884 N.E.2d 335, 339 (Ind. Ct. App. 2008)), aff'd, 2020 U.S. App. LEXIS 3799 (7th Cir. 2020).

515. Id. (citing Wright v. Carter, 622 N.E.2d 170, 171-72 (Ind. 1993)). 
because the decision "was informed by [the doctor's] review of [the patient]'s medical and social history, as well as [another doctor]'s intraoperative pathology consultation." 516 The court viewed the issue as akin to Narducci v. Tedrow, which found the doctrine inappropriate to assess injury and removal of a spleen during colon surgery. ${ }^{517}$ The evaluation necessary to find negligence was beyond that of lay jurors and required "[a]n evaluation of [the doctor]'s conduct and the medical reasons for proceeding with the lobectomy in light of [patient]'s entire clinical picture," necessitating expert testimony. ${ }^{518}$

The same result was reached by Judges James Sweeney II on behalf of the United States District Court for the Southern District of Indiana in an action based on the use of surgical staples. ${ }^{519}$ Despite the plaintiff's attempt to invoke the foreign-object line of cases, the court reasoned that "staples are not accidentally left in a patient after surgery. They are purposely placed to promote healing." 520 Because the staples were placed intentionally and "left in beyond the expected removal date . . . [due to] a medical decision," the question of whether the decisions were negligent required expert testimony to assess. ${ }^{521}$

Medical-malpractice cases were not alone in addressing the doctrine during the survey period. Jones v. Hoosier Energy Rural Electric Cooperative, Inc. rejected application by the estate of a worker who, while working alone, died after apparently falling into a canal. ${ }^{522}$ The court found the doctrine inapplicable because neither exclusivity of control nor irregularity of occurrence was shown. ${ }^{523}$ Not only did the defendant lack control over the relevant bridge, but "[f]alling and injuring one's self proves nothing. Such happenings are commonplace wherever humans go." 524

Similarly, Till v. Dolgencorp, $L L C$ saw invocation of the doctrine unable to prevent summary judgment. ${ }^{525}$ There, a delivery driver was injured when an improperly loaded cart, called roll-tainers, trapped and severely injured his arm. ${ }^{526}$ The injured driver argued the defendant "managed and had exclusive control over the instrumentality that caused the injury - the roll-tainer and the area through which he was instructed to push it. [Defendant] packed the roll-tainers, inspected

516. 112 N.E.3d at $1150-51$.

517. Id. at 1150 (citing Narducci v. Tedrow, 736 N.E.2d 1288, 1292 (Ind. Ct. App. 2000)).

518. Id. at 1151 .

519. Gearnhardt v. United States, No. 2:17-cv-00186-JRS-DLP, 2018 U.S. Dist. LEXIS

192822, at*17-18 (S.D. Ind. Nov. 13, 2018).

520. $I d$.

521. Id.

522. No. 2:18-cv-00443-JRS-DLP, 2019 U.S. Dist. LEXIS 125410, at *7-10 (S.D. Ind. July 29, 2019).

523. $I d$. at $* 9$.

524. Id. at *9-10 (quoting Ogden Estate v. Decatur Cty. Hosp., 509 N.E. 2d 901, 903 (Ind. Ct. App. 1987)) (alteration in original) (quotation marks omitted).

525. No. 1:18-cv-00127-TWP-DLP, 2019 U.S. Dist. LEXIS 117715, at*10-16 (S.D. Ind. July 16, 2019).

526. Id. at *2-6. 
the roll-tainers, loaded the roll-tainers onto the trailer, and sealed the roll-tainers in the trailer." 527 Judge Tanya Pratt, writing for the United States District Court for the Southern District of Indiana, disagreed, reasoning that even though the defendant had packed and loaded the roll-tainers, at the time of the driver's injury, the defendant had relinquished control to the driver who "maintained control over the roll-tainers until they were placed inside the [defendant's] store." ${ }_{228}$ Because, "at most, [defendant] shared control with" the driver, the doctrine "cannot be applied." 529

But not all invocations of the doctrine were unsuccessful. Summary judgment was avoided in Bell v. Wal-Mart Stores East LP through an expansive interpretation of exclusive control. ${ }^{530}$ The case stemmed from injuries to a store patron suffered when an endcap fell on her-the parties disputed whether the patron had run into the endcap with a motorized scooter. ${ }^{531}$ In addressing exclusivity of control, the court found:

"The element of 'exclusive control' is an expansive concept which focuses upon who has the right or power of control and the opportunity to exercise it, rather than actual physical control. "Exclusive control is satisfied if the defendant had control at the time of the alleged negligence." "[P]roof in a res ipsa loquitur case seldom points to a single specific act or omission; typically, it points to several alternative explanations involving negligence without indicating which of them is more probable than the other." Because of this, [plaintiff] need not "eliminate with certainty all other possible causes and inferences[.]"

The court rejected defendants' contention "that they could not have had exclusive control over the endcap because '[i]t is common knowledge that customers will peruse the racks and shelves of retail stores like Walmart while shopping, and in doing so may move merchandise around the store." 5333 That contention missed the mark because it focused on control over merchandise, not shelving. ${ }^{534}$ In the absence of evidence that plaintiff "or any third parties touched the endcap prior to the accident," an issue of material fact remained as to exclusive control. ${ }^{535}$

527. Id. at $* 11$.

528. Id. at $* 15-16$.

529. Id. at $* 16$.

530. No. 3:17-cv-705 JD, 2019 U.S. Dist. LEXIS 41382, at*5-12 (N.D. Ind. Mar. 14, 2019).

531. Id. at $* 3-4$.

532. Id. at *5-6 (quotations in original, citations omitted, first and third alteration in original).

533. Id. at *6 (citations to record omitted, emphasis in original).

534. Id. at *6-7. Notably, even had the issue been one of merchandise, there is authority indicating the absence of " "a hard-and-fast rule that retail stores do not have exclusive control over merchandise on their shelves." Id. at *7 (quoting Assenato v. Target Corp., No. 11 C 6846, 2012 U.S. Dist. LEXIS 8014, at*7 (N.D. Ill. Jan. 24, 2012)).

535. Id. at*8 (citing Norris v. Ross Stores, Inc., 859 A.2d 266, 269 \& 272 (Md. Ct. Spec. App. 2004)) 
The court also found a question of fact, necessitating trial, as to the second element of res ipsa loquitor, "that "the accident is of the type that does not ordinarily happen if those who have the management and control exercise proper care." "536 This element was more easily resolved by the court because Indiana law already recognized, "as a matter of common sense and experience, display racks do not ordinarily fall for no apparent reason on customers in stores. ${ }^{537}$ The question of whether a collision by the plaintiff's scooter was the actual cause, thereby defeating the second element, remained a question for the jury. ${ }^{538}$

Exposure to food poisoning also proved a viable instance for reliance on the doctrine. ${ }^{539}$ Addressing whether an instruction on the doctrine was properly given to a jury, the Indiana Court of Appeals observed "that the quantum of evidence necessary for the giving of an instruction 'is deliberately set at a relatively low level in order to assure the right of parties to have the trier of fact determine factual disputes thus preserving the constitutional rights to a trial by jury.", 540 Importantly, the plaintiff need not "exclude every other possibility other than the defendant's negligence as a cause for the plaintiff's injury." 541 Instead, plaintiffs need only "show that the event or occurrence was more probably the result of negligence by relying upon common sense and experience or by expert testimony." 542 Having shown that the plaintiff had no history of abdominal problems, was fine before eating at the defendant restaurant, became violently ill within two hours of consuming food from the restaurant-which correlates with plausible foodborne pathogens - and that other pieces of chicken at the restaurant were undercooked, there was sufficient basis to invoke res ipsa loquitor. ${ }^{543}$

\section{Parol \& Extrinsic Evidence Rule $e^{544}$}

In general, where . . . the parties to an agreement have reduced the

536. Id. at *12 (quoting K-Mart Corp. v. Gipson, 563 N.E.2d 667, 669 (Ind. Ct. App. 1990)).

537. Id. at *12 (quoting Gipson, 563 N.E.2d at 670) (quotation marks omitted).

538. Id. at $* 12-13$.

539. Golden Corral Corp. v. Lenart, 127 N.E.3d 1205, 1219-20 (Ind. Ct. App.), trans. denied, 138 N.E.3d 948 (Ind. 2019).

540. Id. at 1219 (quoting Shull v. B.F. Goodrich Co., 477 N.E.2d 924, 927-28 (Ind. Ct. App. 1985)).

541. Id.

542. Id. (quoting Gold v. Ishak, 720 N.E.2d 1175, 1181 (Ind. Ct. App. 1999)).

543. Id. at 1219-20.

544. In a technical sense, the parol evidence rule may be considered as distinct from the extrinsic evidence rule, with parol evidence constituting a class of extrinsic evidence. See David G. Epstein et al., Extrinsic Evidence, Parol Evidence, and the Parol Evidence Rule: A Call for Courts to Use the Reasoning of the Restatements Rather than the Rhetoric of Common Law, 44 N.M. L. REv. 49, 53-61 (2014). Nevertheless, Indiana and a great many other jurisdictions have not meticulously recognized a distinction, instead using the terms interchangeably. See id. at 56; E. Allan Farnsworth, Contracts, § 7.2, at 416 (4th ed. 2004); Pepka v. Branch, 294 N.E.2d 141, 154 (Ind. Ct. App. 1973) (referring to the rules as a single "parol and extrinsic evidence rule"). 
agreement to a written document and have included an integration clause that the written document embodies the complete agreement between the parties, the parol evidence rule prohibits courts from considering parol or extrinsic evidence for the purpose of varying or adding to the terms of the written contract. ${ }^{545}$

That is because "[t]he goal of contract interpretation under Indiana law is to determine the parties' intent," which requires unambiguous contracts "be given [their] plain and ordinary meaning[s]" and permits extrinsic evidence only where the contract is ambiguous and requiring further insight "to determine the parties' intent." 546 Despite the nomenclature of an evidentiary rule, "[t]he parol evidence rule is a rule of substantive law rather than a rule of evidence. ${ }^{.547}$ This survey covers the issue because it is a matter taken up by other scholarship on evidentiary procedures and acts to control relevancy in contract interpretation under Rule $401 .^{548}$

Several cases provided the following guidance on the parol evidence rule: The rule does not apply to agreements after the execution of a contract, rather, it only applies to "antecedent understandings and negotiations"; ${ }^{549}$ under the Uniform Commercial Code, the parol evidence rule does not apply absent a final written expression or agreement ${ }^{.50}$ an email showing an abbreviated deadline to execute a settlement agreement directly contradicting a provision of the agreement setting a "reasonable period of time" for execution was barred by the rule, ${ }^{551}$ a list containing a wife's premarital property at the time of a premarital agreement should have been permitted as it did not "contradict[] the terms of the agreement, but merely would have provided specific determination of Wife's premarital property at the time the Agreement was executed"; 552 and parol evidence may be admitted to show a written agreement is void or fraudulently

545. Downs v. Radentz, 132 N.E.3d 58, 63-64 (Ind. Ct. App. 2019).

546. Div. Six Sports, Inc. v. Finish Line, Inc., 928 F.3d 631, 635 (7th Cir. 2019) (citations and quotation marks omitted).

547. Kruse Classic Auction Co. v. Aetna Cas. \& Sur. Co., 511 N.E.2d 326, 329 (Ind. Ct. App. 1987); accord Franklin v. White, 493 N.E.2d 161, 165-66 (Ind. 1986). It is a codified rule under the Uniform Commercial Code. See IND. CoDE § 26-1-2-202 (2020).

548. Sims v. Great Am. Life Ins. Co., 469 F.3d 870, 895 (10th Cir. 2006) (Hartz, J., concurring in part and dissenting in part) (" $[\mathrm{I}] \mathrm{f}$, under a state parol-evidence rule, the contract between two parties does not incorporate oral agreements that contradict the terms of the written contract, then evidence of the oral agreement is not relevant under Rule 401.”).

549. R3 Composites Corp. v. G\&S Sales Corp., No. 1:16-cv-387-HAB, 2019 U.S. Dist. LEXIS 96579, at*9 (N.D. Ind. June 5, 2019) (quoting Dicen v. New Sesco, Inc., 839 N.E.2d 684, 688 (Ind. 2005)) (quotation marks omitted).

550. Mid-American Salt, LLC v. Bob \& Dave's Lawn \& Landscape Maint., Inc., No. 1:16-cv285-HAB, 2019 U.S. Dist. LEXIS 157284, at*12 (N.D. Ind. Sep. 16, 2019).

551. Downs v. Radentz, 132 N.E.3d 58, 64-65 (Ind. Ct. App. 2019).

552. Perrill v. Perrill, 126 N.E.3d 834, 844 (Ind. Ct. App.), trans. denied, 137 N.E.3d 917 (Ind. 2019). 
created, meaning that an integration clause does not preclude introduction of "parol evidence to a fact finder [to show a party was] fraudulently induced to execute" agreements, "and, as such, that those agreements do not in fact represent the parties' intended agreements." 553

\section{Spoliation}

Although not embodied in the Indiana Rules of Evidence, the common-law doctrine of spoliation is an important tool in presentation of evidence at trial. "In Indiana, the exclusive possession of facts or evidence by a party, coupled with the suppression of the facts or evidence by that party, may result in an inference that the production of the evidence would be against the interest of the party which suppresses it." ${ }^{, 54}$ If spoliation is established, the inference may take the form of an instruction to the jury that the evidence would have been unfavorable to the party responsible for spoliation. ${ }^{55}$

Although the rule against spoliation has most often been applied to parties who suppress evidence in their possession at the time suit is initiated, "[t]he duty to preserve evidence occurs when a first-party claimant knew, or at the very least, should have known, that litigation was possible, if not probable." ${ }^{556}$ That means spoliation may be found for pre-suit conduct if "the party knew or should have known [a lawsuit] was imminent." 557

The pre-suit duty of preservation resulted in a spoliation instruction in Golden Coral Corp. v. Lenart. ${ }^{558}$ A severe incident of food poisoning from a buffet was the catalyst for the litigation. ${ }^{559}$ Following a verdict in favor of the plaintiff, in which a spoliation instruction was presented to the jury, the court of appeals found the instruction was appropriately given. ${ }^{560}$ The restaurant had a policy of checking and recording "the temperature of [the] food on the buffet" to be kept in logs, preserved for ninety days. ${ }^{561}$ The logs were not preserved beyond the ninety-day window despite the restaurant knowing of the plaintiff's illness and having been contacted by her attorney within the ninety-day period. ${ }^{562}$ That was

553. Jones v. Oakland City Univ. Founded by Gen. Baptists, Inc., 122 N.E.3d 911, 921 (Ind. Ct. App.), trans. denied, 134 N.E.3d 1013 (Ind. 2019).

554. Golden Corral Corp. v. Lenart, 127 N.E.3d 1205, 1217 (Ind. Ct. App.) (citation and quotation marks omitted), trans. denied, 138 N.E.3d 948 (Ind. 2019).

555. See, e.g., id. at 1217-18; see also IND. Model Civil JuRy InSTRUCTION 535 (2019).

556. Golden Corral, 127 N.E.3d at 1217 (citation and quotation marks omitted). Remedies also exist for third-party spoliation claims. N. Ind. Pub. Serv. Co. v. Aqua Envtl. Container Corp., 102 N.E.3d 290, 301 n.8 (Ind. Ct. App. 2018).

557. Id. at 1218 (citation and quotation marks omitted).

558. Id. at 1217-18.

559. Id. at 1210-13.

560. Id. at 1218 .

561. Id. at 1212 .

562. Id. at 1218 . 
enough to justify issuance of the instruction as to the temperature logs. ${ }^{563}$ The court, however, did find error in issuing the jury instruction to cover a specific piece of food that was presented by the plaintiff to an employee of the restaurant to show that the food appeared undercooked. ${ }^{564}$ But that error was deemed harmless. ${ }^{565}$

Further advancing spoliation jurisprudence was a decision from Chief Judge Jane Magnus-Stinson on behalf of the United States District Court for the Southern District of Indiana. ${ }^{566}$ The evidence in that instance was a coupling that may have played a role in the malfunction of a fire-suppression sprinkler resulting in damage to warehouse inventory. ${ }^{567}$ The coupling was lost or misplaced while in the defendant's possession prior to trial. ${ }^{568}$ Based upon the recognition by the defendant's principal that the coupling was important to preserve, the duty to preserve was triggered. ${ }^{569}$ The court further concluded that the storage of the component and its ultimate loss was the product of the defendant's negligence, thereby leading to a finding of spoliation. ${ }^{570}$ Still, the court did not find the imposition of an adverse inference warranted. ${ }^{571}$ Instead, because photographs of the coupling remained, the court was satisfied to prohibit a witness for the defendant from testifying to information garnered from his actual interaction with the coupling, opting to confine his testimony to only what he could ascertain from the photographs. ${ }^{572}$

\section{STATUTORY EVIDENTIARY PROCEDURES}

Where the Indiana Rules of Evidence "do not cover a specific evidence issue, common or statutory law shall apply." ${ }^{, 73}$ Two such evidentiary procedures established under statute are the Protected Person Statute ${ }^{574}$ and the Child's Hearsay Statute, ${ }^{575}$ both of which gained further insight through appellate decisions, over the course of the survey period.

563. Id.

564. Id.

565. Id.

566. Charter Oak Fire Ins. Co. v. FSSI, Inc., No. 1:17-cv-03451-JMS-MPB, 2019 U.S. Dist. LEXIS 122892 (S.D. Ind. July 24, 2019). Because the matter presented pursuant to the federal court's diversity jurisdiction, Indiana law on spoliation governed. $I d$. at *11.

567. Id. at $* 2-3$.

568. Id. at $* 5-7$.

569. Id. at *13-14.

570. Id. at *14-15.

571. Id. at *15-16.

572. Id.

573. IND. EvID. R. 101(b).

574. IND. CODE $§ 35-37-4-6$ (2019).

575. IND. CODE $§ 31-34-13-3$ (2019). 


\section{A. Testimony Under Indiana's Protected Person Statute}

"Indiana Code section 35-37-4-6, known as the 'protected person statute,' provides a list of certain conditions under which evidence that would otherwise be inadmissible will be allowed in cases involving certain crimes against 'protected persons." "'576 A statement or recording of a protected person's testimony may be admissible in evidence if, inter alia, the person testifies at trial or is determined to be unavailable. ${ }^{577}$ One basis for unavailability is met when "the testimony of a psychiatrist, physician, or psychologist, and other evidence, if any, [shows] that the protected person's testifying in the physical presence of the defendant will cause the protected person to suffer serious emotional distress such that the protected person cannot reasonably communicate." ${ }^{578}$ The court of appeals rejected a challenge to admissibility raised on the assertion that the testimony came from a person who was not a licensed psychologist and the licensed psychologist who testified did not personally interview the protected person. ${ }^{579}$ The court's rationale was that "[m]edical professionals, like professionals in many areas, utilize subordinates, and when a medical professional signs off on a subordinate's work product, it becomes the medical professional's work product." 580 Thus, because "a licensed psychologist adopted and ratified the work of her subordinate and made it her own," indicating the protected person would be emotionally distressed by testifying in person, the statute was properly utilized by the trial court. ${ }^{581}$

Another requirement for utilizing the Protected Person Statute is that the witness be available for cross-examination either at the time the video is made or at a protected-person hearing. ${ }^{582}$ Where a protected person is subject to crossexamination at a protected-person hearing, a defendant is not deprived of his or her constitutional right to confrontation merely because the protected person may not have understood, and been responsive to, some of the questions asked on cross-examination. ${ }^{583}$

\section{B. Child's Hearsay Statements in CHINS Proceedings}

A child in need of services ("CHINS") proceeding provides additional allowances for hearsay due to the need to facilitate the testimony of children. "Indiana Code Section 31-34-13-2 provides that a statement or videotape made by a child under age fourteen is admissible as evidence in a CHINS proceeding if certain requirements are met." 584 Those requirements are provided by "Indiana

576. Shoda v. Indiana, 132 N.E.3d 454, 462 (Ind. Ct. App. 2019) (citations omitted).

577. IND. CODE § 35-37-4-6(e)(2) (2019).

578. IND. CODE $\S 35-37-4-6($ e)(2)(B)(i) (2019).

579. Vega v. State, 119 N.E.3d 193, 200 (Ind. Ct. App. 2019).

580. Id.

581. Id.

582. IND. CODE $§ 35-37-4-6(f)$ (2019).

583. Shoda v. Indiana, 132 N.E.3d 454, 462-65 (Ind. Ct. App. 2019).

584. A.M. v. Ind. Dep't of Child Servs., 121 N.E.3d 556, 560 (Ind. Ct. App.), trans. denied, 
Code Section 31-34-13-3, known as the Child Hearsay statute." ${ }^{255}$ In A.M. v. Indiana Department of Child Services, the parents argued that their child's hearsay statements were not reliable and lacked specificity, and were, therefore, inadmissible. ${ }^{586}$ The court rejected the fact-based challenges because there was nothing atypical to the child's interview: the child "could identify body parts that [the f] ather had allegedly touched," the child agreed with the interviewer that she would "only talk about things that really happened," and the child's "statements were consistent throughout the interview, though not particularly detailed, which is typical for a child her age. ${ }^{587}$

\section{ADDITIONAL EVIDENTIARY INSIGHTS}

\section{A. Preinjury Nonuse of Safety Equipment Irrelevant to Causation}

When a person suffers an injury at the hands of another, it may often be said that the person's injuries may have been lessened by pre-injury use of safety equipment. The problem with such arguments, however, is that a diminution in the severity of harm is a question of mitigation, ${ }^{588}$ and "the question of whether mitigation of damages has occurred looks to the acts of the injured party only after the injury has occurred." ${ }^{589}$ It is that logic which has long led Indiana to exclude from evidence acts such as a person's nonuse of a seatbelt prior to a motor-vehicle collision. ${ }^{590}$

Before the Seventh Circuit was the question of whether nonuse of other safety equipment - specifically a hardhat - should also be excluded under Indiana law. ${ }^{591}$ The primary plaintiff ${ }^{592}$ suffered traumatic brain injury after being struck by a falling branch while assisting in removal of dead trees on the defendant's property. ${ }^{593}$ At trial, the plaintiffs moved to exclude all testimony regarding the primary plaintiff's nonuse of a hardhat. ${ }^{594}$ Finding the evidence admissible, the district court denied the motion and instructed the jury that "[e]vidence relating

\footnotetext{
129 N.E.3d 775 (Ind. 2019).

585. Id.

586. Id.

587. Id. at 560-61.

588. Kocher v. Getz, 824 N.E.2d 671, 674 (Ind. 2005).

589. State v. Ingram, 427 N.E.2d 444, 448 (Ind. 1981).

590. Id.; Hopper v. Carey, 716 N.E.2d 566, 571-73 (Ind. Ct. App. 1999); City of Fort Wayne v. Parrish, 32 N.E.3d 275, 277-80 (Ind. Ct. App. 2015). Indiana also excludes evidence of seatbelt nonuse in actions governed by the Indiana Comparative Fault Act by way of statutory mandate. IND. CODE $\S 9-19-10-7$ (a) (2020).

591. Webber v. Butner, 923 F.3d 479 (7th Cir. 2019).

592. The plaintiffs were a husband and wife pursuing recovery for physical injuries to the husband and a derivative claim for loss of consortium on behalf of the wife. Webber v. Butner, No. 1:16-cv-01169-TWP-DML, 2017 U.S. Dist. LEXIS 209062, at*1 (S.D. Ind. Dec. 20, 2017).

593. Webber, 923 F.3d at 481.

594. Id.
} 
to the use of a hardhat is offered to show assumption of risk, comparative fault, and whether [the primary plaintiff] acted as a reasonably careful person. You may not consider it to show whether it would have prevented or altered the extent of [his] injuries." 595

Following a narrow verdict for the defendant based upon the allocation of fault under the Indiana Comparative Fault Act, the plaintiffs appealed, seeking a new trial on the basis of the presentation of evidence to the jury of the primary plaintiff's nonuse of a hardhat. ${ }^{596}$ Because the question of admission turned on whether the evidence was relevant to apportion fault to the primary plaintiff, the analysis focused on the meaning of "fault" as applied to the Indiana Comparative Fault Act. ${ }^{597}$

For guidance, the Seventh Circuit looked to the Indiana Supreme Court's decision in Kocher v. Getz. ${ }^{598}$ There, the court rejected an argument seeking to use post-injury conduct as evidence to guide apportionment of fault. ${ }^{599}$ In the process, the court interpreted the definition of "fault," adding, in dicta:

The phrase "unreasonable failure to avoid an injury or to mitigate damages" included in the definition of "fault" . . . applies only to a plaintiff's conduct before an accident or initial injury. An example of such unreasonable failure to avoid an injury or to mitigate damages would be a claimant's conduct in failing to exercise reasonable care in using appropriate safety devices, e.g., wearing safety goggles while operating machinery that presents a substantial risk of eye damage. ${ }^{600}$

The Seventh Circuit did not, however, find substantial guidance in Indiana's seatbelt caselaw. ${ }^{601}$

Nevertheless, as a matter of Indiana law, the Seventh Circuit found reversible error in allowing admission of hardhat evidence. ${ }^{602}$ The court observed that " $[t]$ he reason the branch fell and struck [the primary plaintiff] had nothing to do with whether he wore a hardhat." 603 "Since there was no causal relationship between [his] lack of a hardhat before the injury and the injury-causing event or the injuries themselves, Indiana law did not provide a basis for admitting th[e]

595. Id. (quotation marks omitted).

596. Id. at 482 .

597. Id. at 482-84. "Fault" is defined at Ind. Code § 34-6-2-45 (2019).

598. Id. at 483-84 (citing Kocher v. Getz, 824 N.E.2d 671, 674-75 (Ind. 2005)) .

599. Kocher, 824 N.E.2d at 673-75.

600. Id. at 674-75; see also Webber, 922 F.3d at 483 (recognizing this language as dicta) (emphasis in original).

601. Webber, 923 F.3d at 485 .

602. Id. at 484-85. Although beyond the scope of this survey, it merits note that the finding that the error was not harmless stemmed from the "razor-thin split when apportioning fault"-i.e. $51 \%$ allocated to plaintiff. $I d$. at 481, 485. Notably, the Indiana Comparative Fault Act permits recovery by an injured person who is allocated not more than 50 percent of fault. $I d$. at 480 .

603. Id. at 484 . 
evidence." ${ }^{604}$ The court illustrated the point with examples:

First, suppose a person does not wear safety goggles while cutting down a tree. That person is then hit on the head by a falling branch, suffering injury. The absence of goggles has nothing to do with the falling branch and the injury he suffered. This arguable "fault" did not contribute to the accident or injury. . . . [T] herefore, evidence and argument to attribute fault for not using safety goggles would be irrelevant.

Second, suppose another person does not wear safety goggles while cutting down a tree. A splinter of wood flies off the chainsaw blade and hits him in the eye. In that case, the failure to wear safety goggles would have been a proximate cause of his injury. If he had been wearing safety goggles, the splinter of wood would not have been able to injure his eye. The injury-causing event and the injury would never have occurred. In that case, evidence of the failure to use safety goggles would be admissible to show fault. ${ }^{605}$

The key takeaway from Webber is that nonuse of safety equipment cannot be admitted to impact the allocation of fault in a personal-injury action governed by Indiana law in the absence of a "causal connection" between the evidence of nonuse and the injury-causing event. ${ }^{606}$

\section{B. Pleadings as Evidence at Trial}

The winding path of civil litigation often leaves initial pleadings forgotten remnants of the early days of a case. Nevertheless, Indiana Trial Rule 9.2(B) ensures that there are circumstances in which the pleadings remain an important part of trial evidence. ${ }^{607}$ One such circumstance presented in Dunlap v. Lange, wherein the trial court erroneously excluded the governing purchase agreement in a breach-of-contract action. ${ }^{608}$ The basis for exclusion was that the plaintiffs did not include the purchase agreement in exchanging final trial exhibits as required by a pretrial order. ${ }^{609}$ With the purchase agreement excluded, the defense was able to successfully have the action involuntarily dismissed. ${ }^{610}$

The purchase agreement, however, was neither a mystery to the parties nor to the court. As required by Trial Rule 9.2(A)(1)(a) ${ }^{611}$ the plaintiffs attached a

604. Id.

605. Id. at $484-85$.

606. Id. at 484 .

607. Ind. R. TRIAL P. 9.2(B).

608. Dunlap v. Lange, 113 N.E.3d 785, 786-88 (Ind. Ct. App. 2018), trans. denied, 123 N.E.3d 133 (Ind. 2019).

609. Id. at 787.

610. Id.

611. IND. R. TRIAL P. 9.2(A)(1)(a). 
copy of it as an exhibit to their complaint. ${ }^{612}$ The defendant "did not deny execution of the [p]urchase [a]greement in either her answer or amended answer." ${ }^{13}$ Accordingly, under Trial Rule 9.2(B), "the instrument, if otherwise admissible, shall be deemed admitted into evidence in the action without proving its execution unless execution be denied under oath in the responsive pleading or by an affidavit filed therewith." ${ }^{14}$ In the absence of any other basis for finding the purchase agreement inadmissible, the Indiana Court of Appeals determined the exclusion amounted to reversible error because the purchase agreement was already "deemed admitted into evidence by operation of Trial Rule 9.2(B), with no other action by the [plaintiffs] required."

\section{CONCLUSION}

As with every survey period, developments in caselaw have continued to shift and mold our understanding of Indiana evidentiary practice, which will continue for years to come.

612. Dunlap, 113 N.E.3d at 786.

613. Id. at 787.

614. Ind. R. TRIAL P. 9.2(B).

615. Dunlap, 113 N.E.3d at 787-88. 